\title{
Proposed Plan for Remedial Action for the Groundwater Operable Unit at the Chemical Plant Area of the Weldon Spring Site, Weldon Spring, Missouri
}

July 1999

prepared by

Environmental Assessment Division, Argonne National Laboratory

prepared for

U.S. Department of Energy, Weldon Spring Site Remedial Action Project, Weldon Spring, Missouri, under Contract W-31-109-Eng-38 
Gy

This report is printed on recycled paper. 


\section{DISCLAIMER}

This report was prepared as an account of work sponsored by an agency of the United States Government. Neither the United States Government nor any agency thereof, nor any of their employees, make any warranty, express or implied, or assumes any legal liability or responsibility for the accuracy, completeness, or usefulness of any information, apparatus, product, or process disclosed, or represents that its use would not infringe privately owned rights. Reference herein to any specific commercial product, process, or service by trade name, trademark, manufacturer, or otherwise does not necessarily constitute or imply its endorsement, recommendation, or favoring by the United States Government or any agency thereof. The views and opinions of authors expressed herein do not necessarily state or reflect those of the United States Government or any agency thereof. 


\section{DISCLAIMER}

Portions of this document may be illegible in electronic image products. Images are produced from the best available original document. 


\section{CONTENTS}

1 INTRODUCTION $\ldots \ldots \ldots \ldots \ldots \ldots \ldots \ldots \ldots \ldots \ldots \ldots \ldots \ldots \ldots \ldots \ldots$

2 SITE BACKGROUND $\ldots \ldots \ldots \ldots \ldots \ldots \ldots \ldots \ldots \ldots \ldots \ldots \ldots \ldots \ldots$

2.1 Site Description and Potential Areas of Contamination $\ldots \ldots \ldots \ldots \ldots \ldots \ldots$.

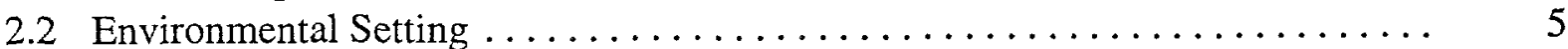

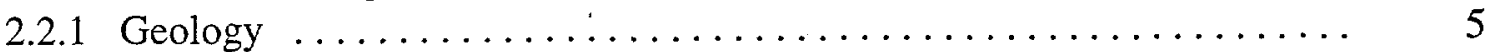

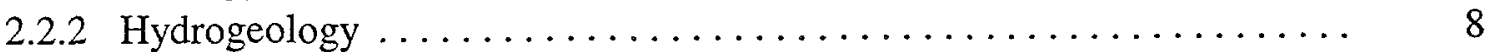

2.2 .3 Surface Water ................................ 10

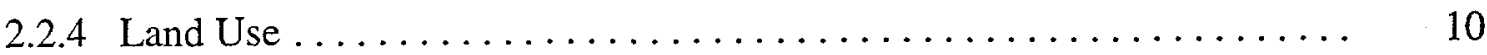

2.3 Nature and Extent of Contamination $\ldots \ldots \ldots \ldots \ldots \ldots \ldots \ldots \ldots \ldots \ldots \ldots \ldots$

2.3 .1 Groundwater . . . . . . . . . . . . . . . . . . . . . . . . 11

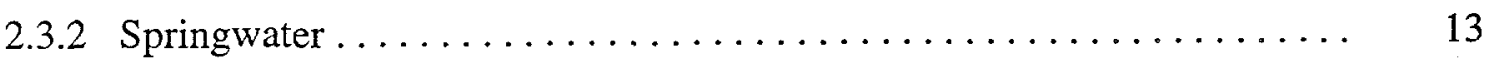

3 SCOPE AND ROLE OF THE PROPOSED ACTION $\ldots \ldots \ldots \ldots \ldots \ldots \ldots \ldots$

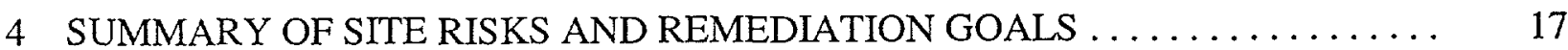

4.1 Human Health Risk Assessment $\ldots \ldots \ldots \ldots \ldots \ldots \ldots \ldots \ldots \ldots \ldots \ldots \ldots$

4.2 Ecological Assessment $\ldots \ldots \ldots \ldots \ldots \ldots \ldots \ldots \ldots \ldots \ldots \ldots \ldots \ldots \ldots$

4.3 Remediation Goals for the Chemical Plant Groundwater . . . . . . . . . . . 20

5 SCREENING OF PRELIMINARY ALTERNATIVES $\ldots \ldots \ldots \ldots \ldots \ldots \ldots \ldots . \ldots$

5.1 Preliminary Alternatives Considered . . . . . . . . . . . . . . . . 21

5.2 Alternatives Eliminated from Consideration $\ldots \ldots \ldots \ldots \ldots \ldots \ldots \ldots \ldots \ldots$

5.3 Alternatives Retained for Further Evaluation $\ldots \ldots \ldots \ldots \ldots \ldots \ldots \ldots \ldots$

6 DESCRIPTION AND ANALYSIS OF FINAL ALTERNATIVES . . . . . . . . . 29

6.1 Description of Final Alternatives $\ldots \ldots \ldots \ldots \ldots \ldots \ldots \ldots \ldots \ldots \ldots \ldots \ldots$

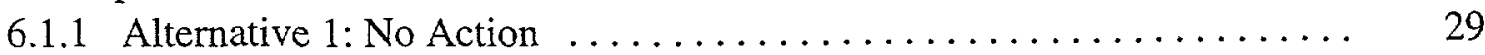

6.1 .2 Alternative 2 : Long-Term Monitoring . . . . . . . . . . . . . . 29

6.1.3 Alternative 3 : Monitored Natural Attenuation ............... 30

6.1.4 Alternative 4: Groundwater Removal and On-Site Treatment Using GAC and Ion Exchange ................... 30

6.1.5 Alternative 7: Removal and On-Site Treatment of Groundwater

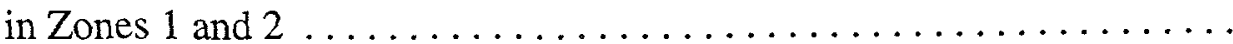




\section{CONTENTS (Cont.)}

6.1.6 Alternative 8: In-Situ Treatment of TCE Using In-Well

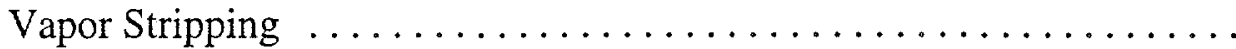

6.1.7 Alternative 9: In-Situ Chemical Oxidation of TCE

Using Fenton-Like Reagents $\ldots \ldots \ldots \ldots \ldots \ldots \ldots \ldots \ldots \ldots \ldots \ldots \ldots \ldots$

6.2 Comparative Analysis of Final Alternatives ................... 33

6.2.1 Overall Protection of Human Health and the Environment ......... 34

6.2.2 Compliance with Potential ARARs .................... 37

6.2.3 Long-Term Effectiveness and Permanence ............... 38

6.2.4 Reduction of Toxicity, Mobility, or Volume through Treatment ....... 39

6.2.5 Short-Term Effectiveness ............................ 39

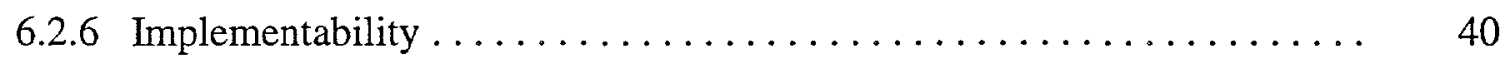

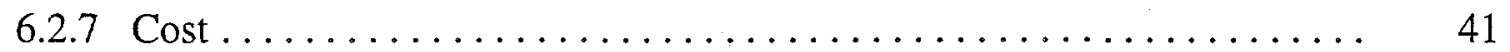

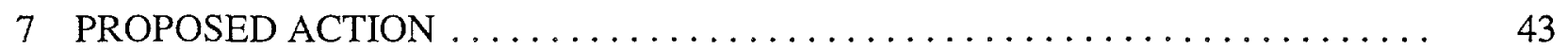

8 COMMUNITY PARTICIPATION $\ldots \ldots \ldots \ldots \ldots \ldots \ldots \ldots \ldots \ldots \ldots \ldots \ldots \ldots \ldots \ldots$

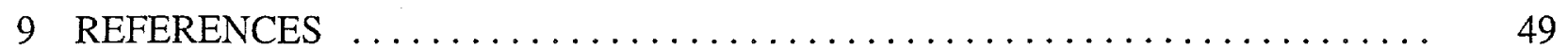

\section{TABLES}

1 Summary of the Human Health Risk Assessment Results for the

Groundwater Operable Unit . .

2 Contaminants of Concern for Zones at the Chemical Plant Area .............. 24

3 Estimated Cleanup Times for Monitored Natural Attenuation and the Pump and Treat Method

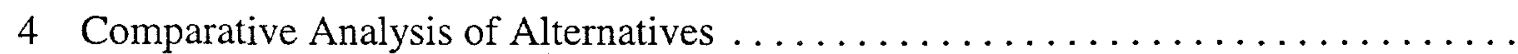

\section{FIGURES}

1 Locations of the Weldon Spring Chemical Plant Area and

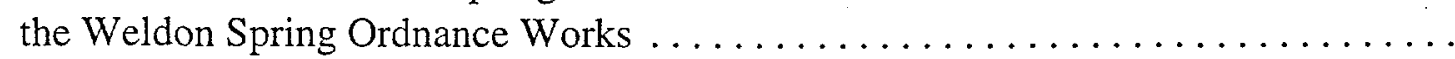

2 Map of the Chemical Plant Area and Immediate Vicinity $\ldots \ldots \ldots \ldots \ldots \ldots$ 


\section{FIGURES (Cont.)}

3 Original Layout of the Chemical Plant Area $\ldots \ldots \ldots \ldots \ldots \ldots \ldots \ldots \ldots$

4 Springs and Drainage Areas in the Chemical Plant Area and the

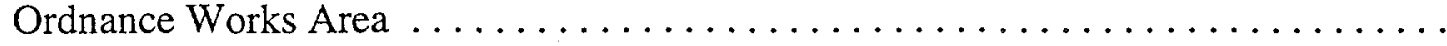

5 Remediation Components for the Weldon Spring Site $\ldots \ldots \ldots \ldots \ldots \ldots \ldots . . \ldots$

6 Contamination Zones at the Weldon Spring Chemical Plant Area $\ldots \ldots \ldots \ldots \ldots .22$ 


\section{NOTATION}

The following is a list of the acronyms, initialisms, and abbreviations (including units of measure) used in this document.

\section{ACRONYMS, INITIALISMS, AND ABBREVIATIONS}

\section{General}

$\begin{array}{ll}\text { ARAR } & \text { applicable or relevant and appropriate requirement } \\ \text { BRA } & \text { baseline risk assessment } \\ \text { CERCLA } & \text { Comprehensive Environmental Response, Compensation, and Liability Act } \\ \mathrm{CO}_{2} & \text { carbon dioxide } \\ \text { DA } & \text { U.S. Department of the Army } \\ \text { DOE } & \text { U.S. Department of Energy } \\ \text { EPA } & \text { U.S. Environmental Protection Agency } \\ \text { FeSO } & \text { ferrous sulfate } \\ \text { FS } & \text { feasibility study } \\ \text { GAC } & \text { granular activated carbon } \\ \text { GWOU } & \text { groundwater operable unit } \\ \text { MCL } & \text { maximum contaminant level } \\ \text { MDC } & \text { Missouri Department of Conservation } \\ \text { MNA } & \text { monitored natural attenuation } \\ \text { NCP } & \text { National Oil and Hazardous Substances Pollution Contingency Plan } \\ \text { RA } & \text { remedial action } \\ \text { RD } & \text { remedial design } \\ \text { RI } & \text { remedial investigation } \\ \text { ROD } & \text { Record of Decision } \\ \text { WSSRAP } & \text { Weldon Spring Site Remedial Action Project } \\ \text { WSTA } & \text { Weldon Spring Training Area } \\ \end{array}$

\section{Chemicals}

$\begin{array}{ll}\text { 1,3-DNB } & \text { 1,3-dinitrobenzene } \\ \text { DNT } & \text { dinitrotoluene } \\ \text { 2-amino-4,6-DNT } & \text { 2-amino-4,6-dinitrotoluene } \\ \text { 4-amino-2,6-DNT } & \text { 4-amino-2,6-dinitrotoluene } \\ \text { 2,4-DNT } & \text { 2,4-dinitrotoluene }\end{array}$




\begin{tabular}{|c|c|}
\hline \multicolumn{2}{|c|}{$2,6-\mathrm{DNT}$} \\
\hline \multicolumn{2}{|c|}{ TCE } \\
\hline \multicolumn{2}{|c|}{$1,3,5-\mathrm{TNB}$} \\
\hline \multicolumn{2}{|c|}{ TNT } \\
\hline \multicolumn{2}{|c|}{$2,4,6-\mathrm{TNT}$} \\
\hline \multicolumn{2}{|c|}{ UNITS OF MEASURE } \\
\hline $\mathrm{ft}$ & foot (feet) \\
\hline $\begin{array}{l}\text { gpm } \\
\text { ha }\end{array}$ & $\begin{array}{l}\text { gallon }(\mathrm{s}) \text { per minute } \\
\text { hectare }(\mathrm{s})\end{array}$ \\
\hline & kilometer(s) \\
\hline $\mathrm{L}$ & $\operatorname{liter}(\mathrm{s})$ \\
\hline$\mu g$ & $\operatorname{microgram}(\mathrm{s})$ \\
\hline $\mathrm{m}$ & meter(s) \\
\hline $\mathrm{mg}$ & milligram(s) \\
\hline $\mathrm{mi}$ & mile(s) \\
\hline $\min$ & minute(s) \\
\hline & picocurie(s) \\
\hline
\end{tabular}

2,6-dinitrotoluene trichloroethylene

1,3,5-trinitrobenzene trinitrotoluene

2,4,6-trinitrotoluene 
July 1999 


\section{PROPOSED PLAN FOR REMEDIAL ACTION \\ FOR THE GROUNDWATER OPERABLE UNIT AT THE \\ CHEMICAL PLANT AREA OF THE WELDON SPRING SITE, WELDON SPRING, MISSOURI}

\section{INTRODUCTION}

This Proposed Plan addresses the remediation of groundwater contamination at the chemical plant area of the Weldon Spring site in Weldon Spring, Missouri. The site is located approximately $48 \mathrm{~km}$ (30 mi) west of St. Louis in St. Charles County (Figure 1). Remedial activities at the site will be conducted in accordance with the Comprehensive Environmental Response, Compensation, and Liability Act (CERCLA). The U.S. Department of Energy (DOE), in conjunction with the U.S. Department of the Army (DA), conducted a joint remedial investigation/feasibility study (RI/FS) to allow for a comprehensive evaluation of groundwater conditions at the Weldon Spring chemical plant area and the Weldon Spring ordnance works area, which is an Army site adjacent to the chemical plant area. Consistent with DOE policy, National Environmental Policy Act (NEPA) values have been incorporated into the CERCLA process. That is, the analysis conducted and presented in the RI/FS reports (DOE and DA 1997a,b; 1998) included an evaluation of environmental impacts that is comparable to that performed under NEPA.

This Proposed Plan summarizes information about chemical plant area groundwater that is presented in the following documents:

1. The Remedial Investigation (RI), which presents information on the nature and extent of contamination (DOE and DA 1997b);

2. The Baseline Risk Assessment (BRA), which evaluates impacts to human health and the environment that could occur if no cleanup action of the groundwater were taken (DOE and DA 1997a); and

3. The Feasibility Study (FS) (DOE and DA 1998) and the Supplemental FS (DOE 1999), which develop and evaluate remedial action alternatives for groundwater remediation.

This Proposed Plan is required under CERCLA. The purpose of the Proposed Plan is to:

- Present to the public a notice and a brief analysis of the remedial action alternatives developed in the FS; 


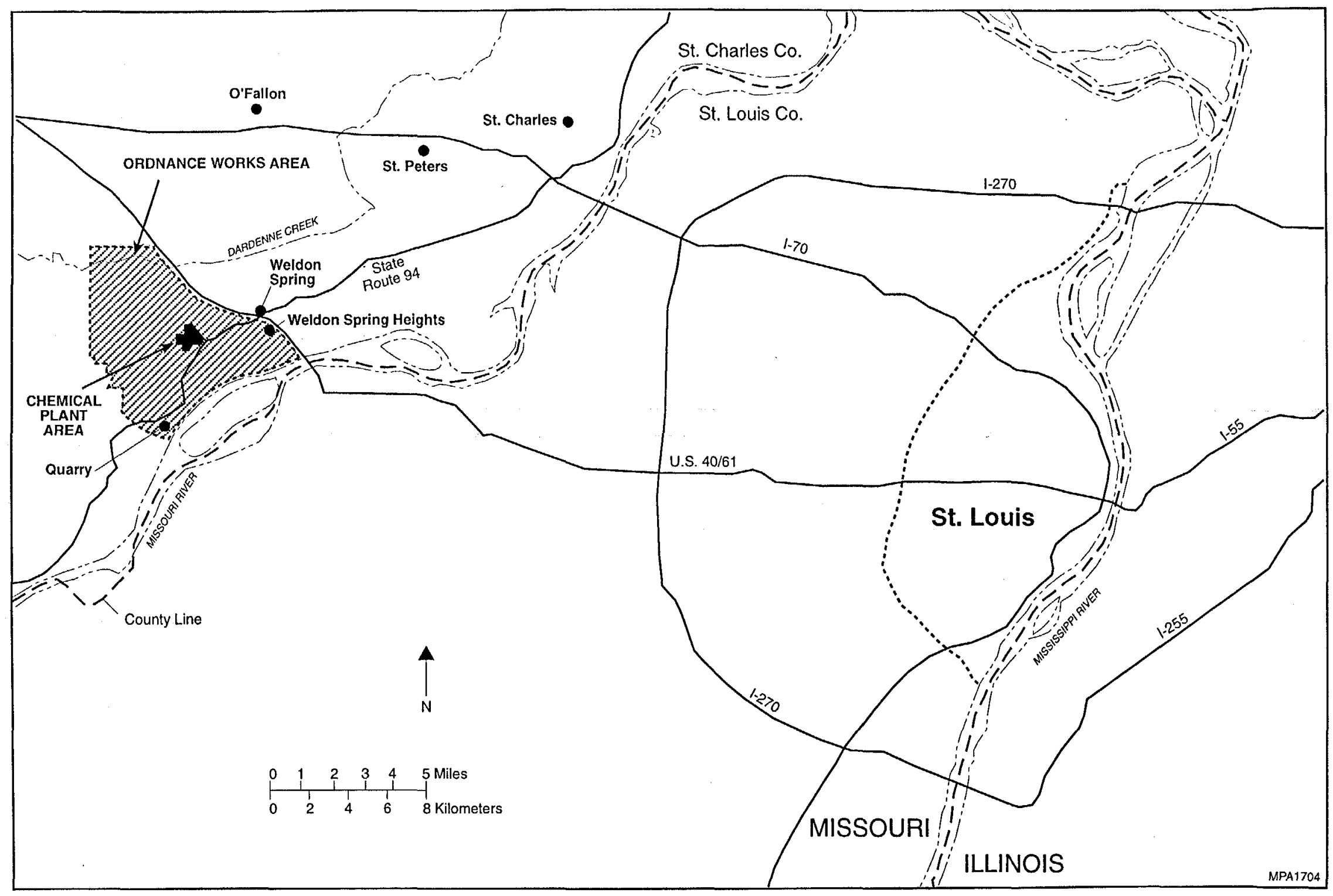

FIGURE 1 Locations of the Weldon Spring Chemical Plant Area and the Weldon Spring Ordnance Works 
- Identify and present the rationale for the proposed remedial action alternative identified in this Proposed Plan;

- Summarize key information from the RI, BRA, and FS; and

- Inform the public of its role in the remedial selection process and provide the public the opportunity to participate in that process.

Under current and likely foreseeable future land use conditions, the groundwater at the chemical plant area poses no imminent risk to human health or the environment. The groundwater is not used at the site. None of the domestic wells located in the area of influence from the chemical plant area are active. Existing wells screened in the same geologic units are separated from the aquifer present beneath the chemical plant area by a regional groundwater divide (Dardenne Creek; see Figure 1) and, therefore, cannot be affected by the site. The proposed remedial action alternative presented in this Proposed Plan involves active remediation of trichloroethylene (TCE)-contaminated groundwater in close proximity to the raffinate pits area of the chemical plant and allows for natural abatement of other contaminant concentrations to proceed. Such abatement is expected to occur naturally over time because the sources of contamination that are being addressed under the chemical plant Record of Decision (ROD) (DOE 1993) would no longer be present, and further contamination of groundwater would not occur after these sources have been removed. The progress of the natural remediation would be monitored until acceptable levels are reached.

This alternative was identified from among nine potential remedial action alternatives that were presented in the FS (DOE and DA 1998). These nine alternatives were developed after careful analysis of available geological, environmental, and human health and ecological risk data, and an evaluation of the effectiveness, implementability, and cost of the various technologies available for groundwater remediation at the chemical plant area. However, final selection of the remedial action alternative has not yet been made; the alternative selected for implementation will be documented in a separate ROD for the ground water operable unit (GWOU), following receipt and consideration of public comments on this plan and any significant new information that may become available. Public input may result in modifications to the ultimate remedial action selected; therefore, public comment on this plan and its supporting documents is an important element of the decision-making process.

DOE encourages public review and comment on this proposed remedial action plan for groundwater at the chemical plant area. Additional details about the site and the remedial action alternatives may be found in the RI (DOE and DA 1997b), BRA (DOE and DA 1997a), and FS (DOE and DA 1998) and in supporting technical reports in the Administrative Record. The remedial action alternatives are evaluated in detail in Chapters 3, 4, and 5 of the FS and are summarized in Chapters 4 and 5 of this Proposed Plan. 
The remainder of this Proposed Plan is organized as follows:

- Chapter 2 presents the history and environmental setting of the chemical plant area and a summary of the nature and extent of contamination,

- Chapter 3 describes the scope and role of the proposed action,

- Chapter 4 summarizes the human health and ecological risks from groundwater contamination at the site and presents remediation goals for groundwater,

- Chapter 5 summarizes the screening process for the nine preliminary remedial action alternatives considered,

- Chapter 6 describes the final remedial action alternatives considered for the remedial action,

- Chapter 7 presents the proposed remedial action alternative, and

- Chapter 8 describes the community's role in this action. 


\section{SITE BACKGROUND}

\subsection{SITE DESCRIPTION AND POTENTIAL AREAS OF CONTAMINATION}

The 88-ha (217-acre) chemical plant area lies within the boundaries of the ordnance works area (Figure 2). The chemical plant was used for trinitrotoluene (TNT) and dinitrotoluene (DNT) production from 1941 to 1945 and later as a uranium-processing facility from 1957 to 1966 . The sources of contamination at the chemical plant area are those shown in the original layout of the chemical plant area (Figure 3). These consisted of approximately 40 buildings, four waste retention ponds (referred to as raffinate pits), two ponds (Ash Pond and Frog Pond), and two former dumps (north and south). Remediation of the buildings, Frog Pond, and the north dump has been completed. The remaining source areas are in the process of being remediated or are scheduled for cleanup within the next year. The chemical plant is currently fenced to restrict public access. Burgermeister Spring, which is hydrologically connected to the chemical plant area groundwater, is in the August A. Busch Memorial Conservation Area.

\subsection{ENVIRONMENTAL SETTING}

The geology and hydrogeology of the Weldon Spring area govern the rate and path of groundwater flow. Transport of contaminants within the groundwater depends on the geology and hydrogeology of the area, as well as on the physical and chemical properties of the contaminants. Land use in the surrounding areas affects the potential for human or ecological exposure to any contaminants the groundwater may contain.

\subsubsection{Geology}

Locally, the subsurface consists of porous, unconsolidated deposits that unconformably overlie bedrock. This unconsolidated overburden material consists primarily of modified loess, glacial drift, preglacial deposits, and residuum (DOE and DA 1997b). The thickness of these glacial and preglacial deposits, known as the "overburden," generally ranges from 4 to $18 \mathrm{~m}$ (13 to $59 \mathrm{ft}$ ) across the chemical plant area.

The Burlington-Keokuk Limestone, the uppermost bedrock unit at the chemical plant area, has been separated into two subunits, the weathered and unweathered. The weathered unit ranges in thickness from 3 to $17 \mathrm{~m}$ (10 to $55 \mathrm{ft}$ ). At the chemical plant area, fracturing in the bedrock is predominantly horizontal. Solution features are common in the weathered portion of the BurlingtonKeokuk Limestone and range from pinpoint vugs to small zones of core loss, typically 


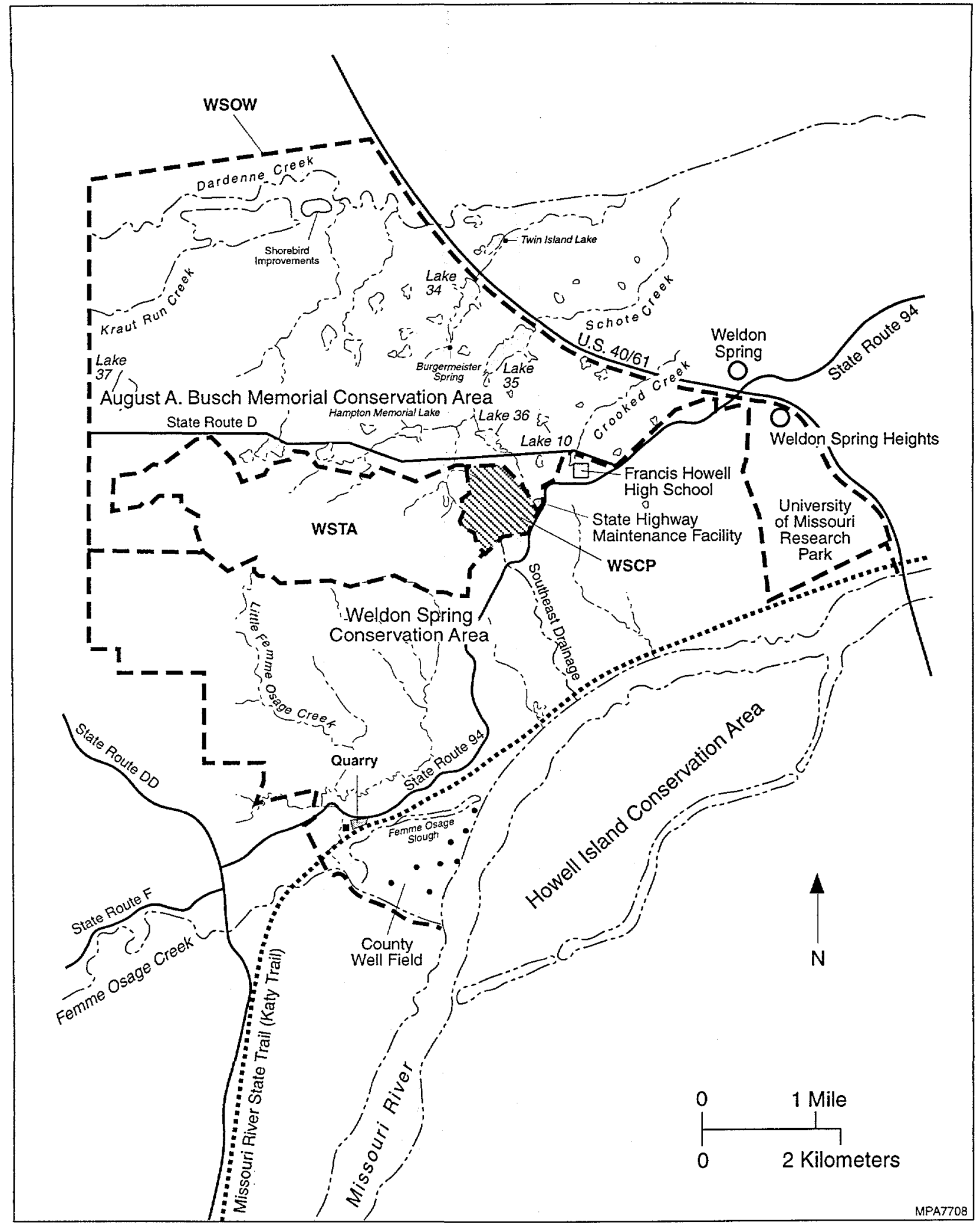

FIGURE 2 Map of the Chemical Plant Area and Immediate Vicinity 


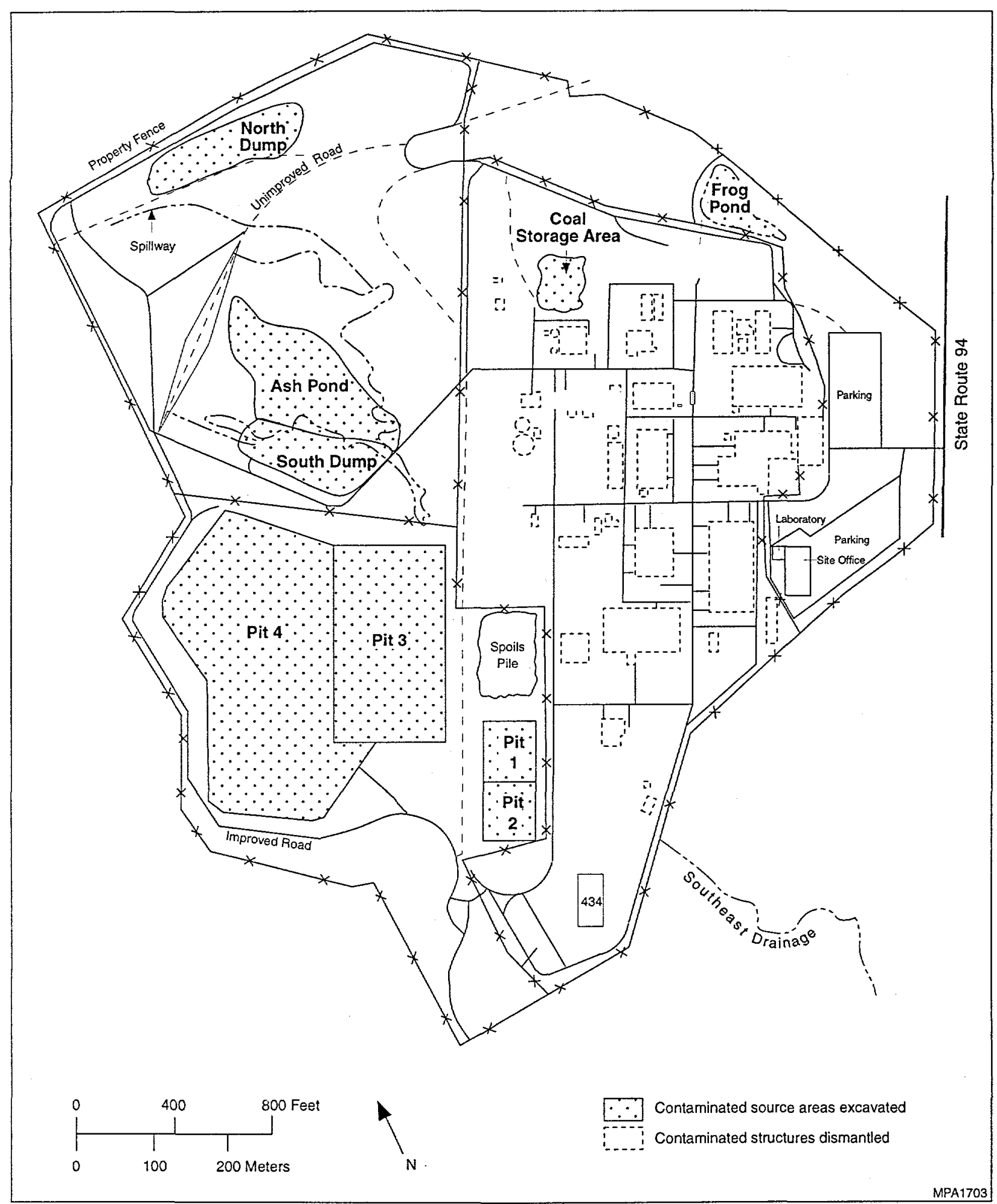

FIGURE 3 Original Layout of the Chemical Plant Area 
less than $1.5 \mathrm{~m}(5 \mathrm{ft})$. The larger zones in many cases appear to be at least partially filled with clay or clay mixture (DOE 1992). Significantly fewer horizontal and vertical fractures exist in the unweathered unit than in the weathered unit. Field data indicate a decrease in hydraulic conductivity with depth, which is attributed to decreased weathering. The size, abundance, and geometry of the open fractures within the bedrock affect the transport of groundwater and contaminants through the bedrock.

\subsubsection{Hydrogeology}

There are three bedrock aquifers in the vicinity of the Weldon Spring site: a shallow unconfined aquifer (although it may be locally confined); a middle confined aquifer; and a deep confined aquifer. An additional shallow, alluvial aquifer is present near the Weldon Spring quarry adjacent to the Missouri River. In St. Charles County, the shallow and middle aquifers are primarily used for rural domestic water supply. This usage occurs outside of the influence of the groundwater contamination at the chemical plant area. The shallow alluvial aquifer near the Missouri River supplies drinking water through the St. Charles County well field. At the Weldon Spring site, no groundwater is currently used.

Because the shallow unconfined aquifer has been affected by former activities at the chemical plant area, it is the groundwater system of primary interest in the Weldon Spring area. This aquifer consists of the Burlington-Keokuk Limestone and the Fern Glen Formation, both limestone units, and, in some locations, the overburden. The principal recharge to this shallow groundwater system is through infiltration of precipitation from the overburden or from losing streams. The water table elevation fluctuates seasonally and with precipitation, but remains within the upper bedrock or overburden. An east-west trending groundwater divide, which coincides with the topographic highpoint of the area, results in two distinct drainage systems.

At the chemical plant area, shallow groundwater north of the divide flows to the north and into a karst conduit system that discharges at Burgermeister Spring (Figure 4). Transport through this conduit is very rapid. Water discharged at Burgermeister Spring then mixes with other surface water and with ponded water in Lake 34. Any dissolved contaminants in the discharged groundwater are then subject to extensive dilution and physical and chemical degradation. Because most of the shallow groundwater beneath the chemical plant area discharges to the surface in the vicinity of Burgermeister Spring, the spring defines the northern-most extent of direct groundwater transport from the site and provides an ideal location for monitoring end-point contaminant concentrations.

Groundwater south of the divide at the chemical plant area flows south to southeast toward the Missouri River, primarily through the Southeast Drainage. Because this drainage has losing stream segments in its upper reaches, mixing between groundwater and surface water occurs. As with Burgermeister Spring, springs in the Southeast Drainage act as end points of direct groundwater 


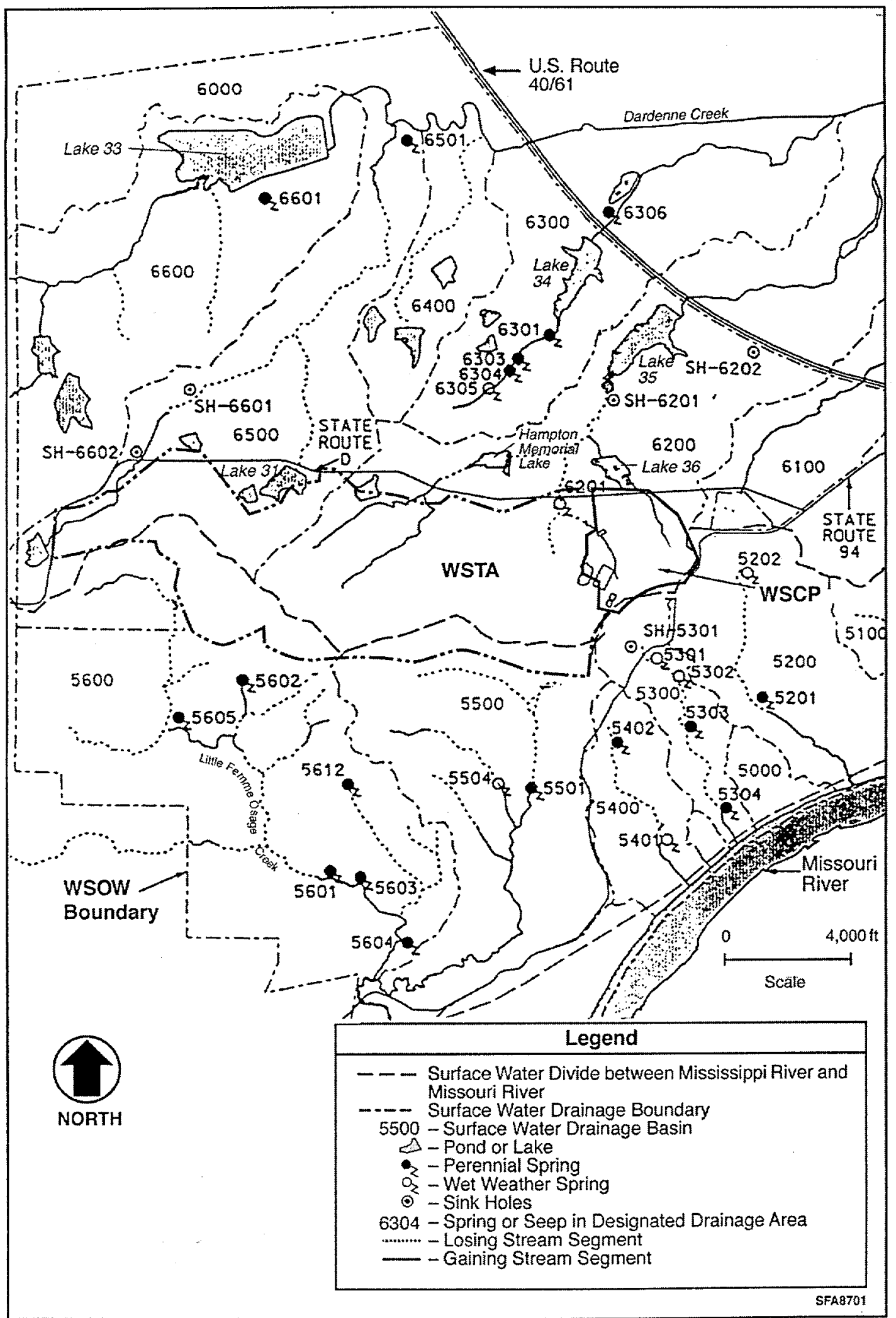

FIGURE 4 Springs and Drainage Areas in the Chemical Plant Area and the Ordnance Works Area 
transport from the chemical plant area and provide ideal locations for monitoring groundwater contamination. Data from groundwater (MW-4026) downgradient of the springs indicate no impact.

The shallow groundwater system beneath the chemical plant area is hydrogeologically complex and is characterized by fractures, conduits, paleochannels, and dissolution/weathering features. Because of these features, the aquifer exhibits highly heterogeneous and anisotropic values in conductivity and transmissivity (ease with which a porous material allows water to flow) from place to place. Recent pump tests performed in July 1998 to determine the effects of groundwater withdrawal on the aquifer further demonstrated the variability of the aquifer. In one location, pumping at a rate of less than $3.8 \mathrm{~L} / \mathrm{min}$ ( 1 gallon per minute [gpm]) could not be sustained. In a second location approximately $30 \mathrm{~m}$ (100 ft). away, water could be pumped, but at a rate of less than $37.9 \mathrm{~L} / \mathrm{min}(10 \mathrm{gpm})$, which is a low value from a pump and treat perspective. Even with this low rate of pumping, the shallow groundwater system could not recharge to sustain this rate, which resulted in the water level in the well falling below the depth of the pump. Once pumping stopped, recovery of the groundwater level was very slow, and full recovery to water levels prior to testing still has not been achieved.

\subsubsection{Surface Water}

The chemical plant area is located on an east-west drainage divide between the Missouri and Mississippi watersheds. At the chemical plant area, surface drainage to the south of the divide generally flows through the Southeast Drainage and discharges to the Missouri River. Surface drainage to the north of the divide flows toward Dardenne Creek and its tributaries. Schote Creek, the largest of the tributaries, drains a major portion of the chemical plant area. Dardenne Creek flows east to the Mississippi River.

\subsubsection{Land Use}

The Weldon Spring site is located in St. Charles County, which has a population of approximately 100,000 . The largest city in the county is St. Charles, which is located approximately $24 \mathrm{~km}$ (15 mi) northeast of the site and has a population of about 50,000 (DOE 1998b).

The chemical plant area is fenced, and access by the general public is restricted. Adjacent to the chemical plant area, portions of the Weldon Spring Training Area (WSTA) that are within the ordnance works area are currently used for field training and outdoor maneuvers by the U.S. Army Reserve, the Missouri Army National Guard, and other military and police units. An estimated 3,300 local Army reservists and 3,400 other reserve troops use the training area each year. The DA intends to continue using the WSTA for future training activities. 
A large portion of the ordnance works area has been converted into conservation areas. The August A. Busch Memorial Conservation Area and the Weldon Spring Conservation Area (see Figure 2) are managed by the Missouri Department of Conservation (MDC) and are open throughout the year for recreational use. These areas receive an estimated 1.2 million visitors each year.

A state highway maintenance facility just east of the chemical plant area employs nine fulltime staff and one mechanic. The former staff housing complex for the ordnance works area, located southeast of the intersection of State Route 94 and U.S. Route 40/61, is currently a private housing development known as Weldon Spring Heights; it has about 80 residents.

Francis Howell High School, located about $1 \mathrm{~km}(0.6 \mathrm{mi})$ east of the chemical plant area, employs about 175 faculty and staff (including employees at the Francis Howell Administration Annex) and is attended by about 1,930 students.

\subsection{NATURE AND EXTENT OF CONTAMINATION}

As presented in the RI report (DOE and DA 1997b), the nature and extent of contamination within the groundwater system for the chemical plant area was jointly evaluated with that of the ordnance works area by using data collected during DOE and DA monitoring programs from 1987 through 1995 and a joint sampling effort conducted in 1995. Data for the chemical plant area and the ordnance works area were combined and evaluated together because the groundwater system is continuous beneath both areas. Data obtained since 1995 from the chemical plant area monitoring wells and springs were also reviewed and are summarized in this section to provide the latest contaminant profile.

\subsubsection{Groundwater}

On the basis of the results of the evaluation in the RI (DOE and DA 1997b) and BRA (DOE and DA 1997a), the primary contaminants in chemical plant area groundwater are TCE, nitroaromatic compounds, nitrate, and uranium.

TCE contamination in groundwater is a recent occurrence (i.e., 1996). Contamination is localized at the chemical plant area, primarily in the vicinity of the raffinate pits. The horizontal extent of contamination extends from east of Raffinate Pit 3 to the south and southeast of Raffinate Pit 4, just beyond the adjacent boundary with the WSTA (see Figure 3). Contamination is limited to seven monitoring wells that are open to the weathered portion of the aquifer. In 1996, TCE concentrations in groundwater ranged from 1 to $9,000 \mu \mathrm{g} / \mathrm{L}$. The maximum concentration is a onetime, but analytically suspect, value; the next highest concentration detected was $1,100 \mu \mathrm{g} / \mathrm{L}$. 
Post-1996 concentrations have ranged from 0.6 to $1,300 \mu \mathrm{g} / \mathrm{L}$. Decreasing trends in concentrations have been observed in wells located in the area of TCE-contaminated groundwater. Levels have decreased by 150 to $900 \%$ since TCE was discovered in groundwater at the chemical plant.

The extent of uranium contamination in groundwater is primarily limited to the chemical plant area and nearby vicinity. Contamination occurs predominantly in the overburden and weathered units of the aquifer. Recent data collected for uranium in 1997 to 1998 from the 56 monitoring wells ranged from 0.02 to $55 \mathrm{pCi} / \mathrm{L}$. The maximum concentration of $55 \mathrm{pCi} / \mathrm{L}$ was detected in a well where previous concentrations were at background levels. This well is located in the raffinate pit area and may have been affected by recent sludge removal and other remediation activities in the raffinate pit area. The next three highest uranium concentrations are 17,20 , and $12 \mathrm{pCi} / \mathrm{L}$, respectively. Analysis of uranium data for 1995 through 1998 indicates that uranium concentrations are generally static at all of the monitored locations with the exception of the well by the raffinate pit area. Excavation activities may have resulted in temporary slight increases in concentrations at these wells (MK-Ferguson 1999).

Similar to uranium, nitrate contamination is primarily limited to the chemical plant area and nearby vicinity. The highest concentrations of nitrate have typically been measured in the vicinity of the raffinate pits and Ash Pond (see Figure 3). Up until 1995, concentrations as high as $12,000 \mathrm{mg} / \mathrm{L}$ were detected. Post-1995 data show a range of 0.02 to $1,000 \mathrm{mg} / \mathrm{L}$. Remediation activities in the raffinate pit area in 1998 have resulted in slight increases in contaminant concentrations in several of the vicinity wells. Review of the nitrate data indicates increases and decreases in concentrations at several areas of the chemical plant. Wells downgradient from Raffinate Pits 1 and 2 have shown 250 to $1000 \%$ decreases in nitrate levels since 1998. Wells in the vicinity of Ash Pond and Raffinate Pits 3 and 4 have recently shown increases in nitrate levels, which is likely due to remediation activities in these areas. As sources are removed and the areas reclaimed, it is expected that levels will begin to decrease.

Nitroaromatic compounds occur sporadically at low levels across the groundwater system; higher levels have generally been detected in the overburden and weathered units of the aquifer. The primary nitroaromatic compounds in groundwater include 2,4-DNT, 2,6-DNT, 1,3,5-trinitrobenzene (1,3,5-TNB), 2,4,6-TNT, and the amino-DNT degradation compounds. Recently, maximum concentrations of $6.0 \mu \mathrm{g} / \mathrm{L}$ for $2,4-\mathrm{DNT} ; 110 \mu \mathrm{g} / \mathrm{L}$ for $2,6-\mathrm{DNT} ; 62 \mu \mathrm{g} / \mathrm{L}$ for $1,3,5-\mathrm{TNB} ; 0.32 \mu \mathrm{g} / \mathrm{L}$ for 1,3 dinitrobenzene (1,3-DNB); and $25 \mu \mathrm{g} / \mathrm{L}$ for 2,4,6-TNT have been detected. Upward trends in nitroaromatic compounds have been observed near the Ash Pond and Frog Pond areas. These increases are likely due to soil excavation activities in the area. 


\subsubsection{Springwater}

The primary contaminants in the springwater at surface springs around the chemical plant area are uranium, nitrate, and nitroaromatic compounds. Low levels (less than $2 \mu \mathrm{g} / \mathrm{L}$ ) of TCE have only been detected in one spring, Spring 6303. Concentrations have been less than $2 \mu \mathrm{g} / \mathrm{L}$. Elevated levels of uranium and nitrate have been routinely detected at Burgermeister Spring (6300 drainage). This spring is a primary discharge point for groundwater originating north of the groundwater divide at the chemical plant area.

Nitrate concentrations at Burgermeister Spring vary with changes in flow rate, but are generally lower than concentrations measured in groundwater. Lower concentrations occur during high flow rates because of dilution. Recent data (1995-1998) for nitrate indicate a range of 3.8 to $47 \mathrm{mg} / \mathrm{L}$.

Uranium concentrations at Burgermeister Spring sampled during higher flow rates have been reported at slightly higher levels than in groundwater because of residuals in the fractured zones. Recent levels (1997-1998) of total uranium range from 1.0 to $150 \mathrm{pCi} / \mathrm{L}$. The historical maximum uranium concentration measured at Burgermeister Spring is $240 \mathrm{pCi} / \mathrm{L}$. Elevated uranium concentrations have also been measured in the Southeast Drainage springs. The historical maximum uranium concentration at these springs is $370 \mathrm{pCi} / \mathrm{L}$; recent levels (1997-1998) ranged from 51 to $120 \mathrm{pCi} / \mathrm{L}$.

Nitroaromatic compounds have been detected in several springs around the chemical plant area and WSTA. Springs 5201 and 5303 (Southeast Drainage) had the highest nitroaromatic concentrations, with levels of 120 and $280 \mu \mathrm{g} / \mathrm{L}$, respectively, for 2,4,6-TNT. Maximum concentrations of the other nitroaromatic compounds (1987-1995) are $11 \mu \mathrm{g} / \mathrm{L}$ for 2,4-DNT; $18 \mu \mathrm{g} / \mathrm{L}$ for $2,6-\mathrm{DNT} ; 15 \mu \mathrm{g} / \mathrm{L}$ for $1,3,5-\mathrm{TNB} ; 1.2 \mu \mathrm{g} / \mathrm{L}$ for $1,3-\mathrm{DNB} ; 1.4 \mu \mathrm{g} / \mathrm{L}$ for nitrobenzene; $19 \mu \mathrm{g} / \mathrm{L}$ for 2-amino-4,6-DNT; and $24 \mu \mathrm{g} / \mathrm{L}$ for 4-amino-2,6-DNT. 


\section{SCOPE AND ROLE OF THE PROPOSED ACTION}

The proposed remedial action constitutes the remaining component of the phased cleanup process for the Weldon Spring Site (Figure 5). This action addresses contaminated groundwater and springs at the chemical plant area. Consistent with this proposed action (and previous actions of the Weldon Spring Site Remedial Action project where residual conditions limit land use), DOE will prepare a plan that defines stewardship responsibilities and is consistent with CERCLA. This plan will address requirements for long-term surveillance, monitoring, and maintenance; land use assurance; roles and responsibilities; and public participation. Like all remedial activities that have been conducted at the Weldon Spring site, stakeholders will have the opportunity to review and provide input to site stewardship planning activities.

The remedial action stipulated in the ROD for the chemical plant (DOE 1993) provided for the removal of the sources of contamination to groundwater. Under the chemical plant remedial action, contaminated soil has been excavated, buildings and structures have been dismantled, and raffinate pits surface water and sludge have been removed, dredged, and treated. The placement of the resulting waste at the on-site disposal cell is currently being completed.

Decisions for the quarry are recorded in the RODs for the bulk waste and quarry residuals operable units (DOE 1990; 1998a). The remedial action to remove and treat contaminated pond water and remove bulk waste has been completed, and the generated waste has been placed at the on-site disposal cell. The remedial action for the quarry residuals operable unit is currently in the remedial design stages, and implementation is expected to begin in the fall of 1999.

The purpose of this proposed remedial action is to provide an appropriate response that would verify that groundwater contaminant levels are decreasing with time as a result of the source removals at the chemical plant and as a result of the continued effects of the natural processes of dilution and dispersion. The proposed remedial action also provides for an active response to reduce TCE levels in groundwater at the chemical plant area (TCE has been found primarily in the areas designated as Zones 1 and 2). 


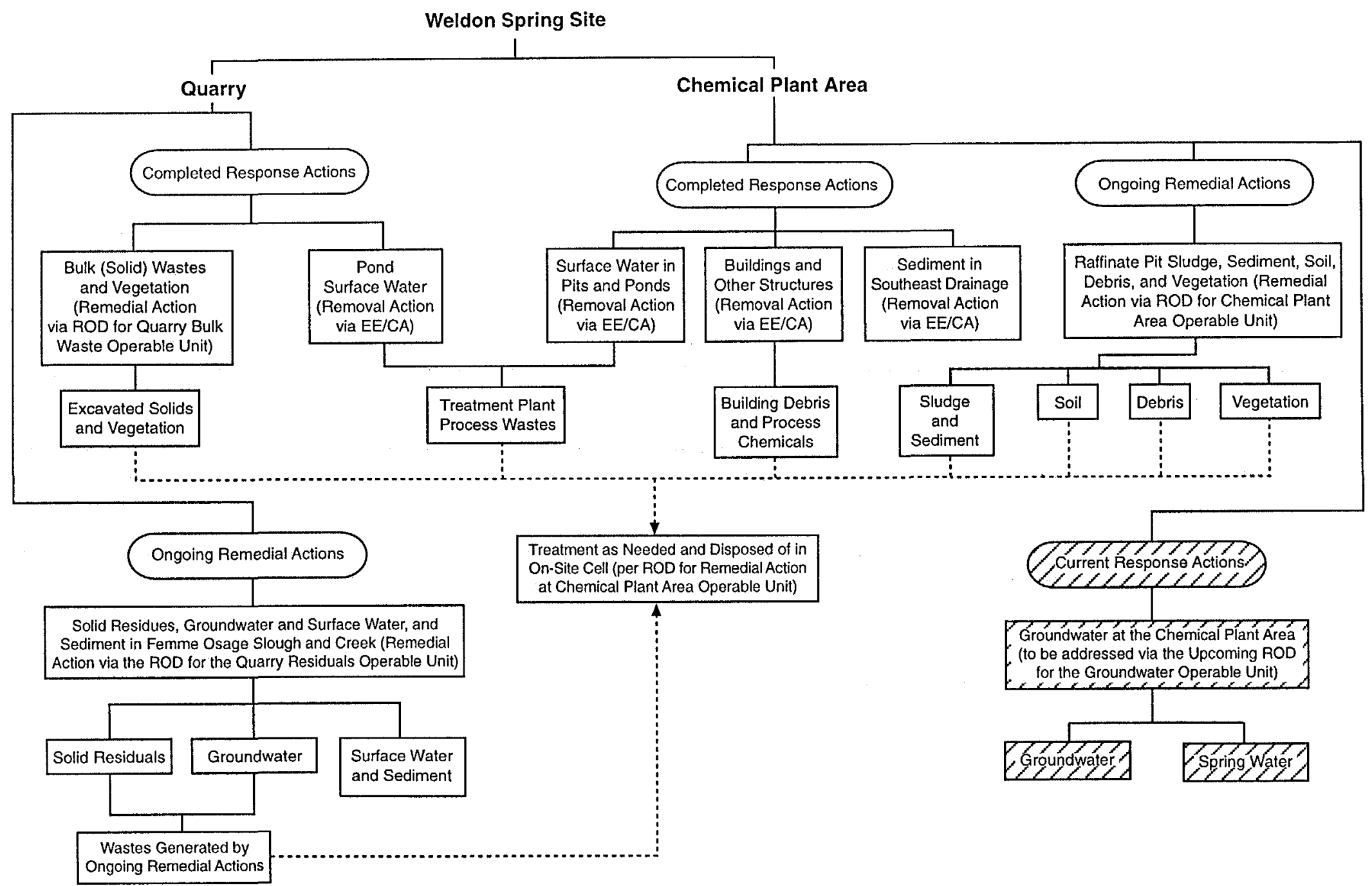

Note: The boxes represent contaminated media addressed by the project's cleanup actions for the chemical plant area and the quarry; they are connected by solid lines to the appropriate phase of site cleanup. Dashed lines identify wastes generated as a result of the completed and ongoing response actions and that are being treated and disposed of in the on-site cell at the chemical plant
area. Boxes with cross-hatching constitute contaminated media that are being addressed as part of the GWOU and this BOD. The GWOU is the final of four operable units for the Weldon Spring 


\section{SUMMARY OF SITE RISKS AND REMEDIATION GOALS}

As part of the joint DOE and DA RI/FS, potential risks to human health and the environment from groundwater and springwater contamination were evaluated for the chemical plant area and the ordnance works area on the basis of current and likely future land uses. Foreseeable future land use (i.e., the next 30 years or so) at both the chemical plant area and the ordnance works area is likely to be recreational, which is the same as current land use. Accordingly, consistent with CERCLA, potential risks were estimated with reference to current and likely foreseeable future recreational users. ${ }^{1}$ Table 1 gives the results of the human health risk assessment performed. The results of the risk assessment were used to determine areas and contaminants that may require remediation.

\subsection{HUMAN HEALTH RISK ASSESSMENT}

Potential cancer risks for the recreational visitor posed by exposure to radiation and chemicals were assessed by using standard methods developed by the U.S. Environmental Protection Agency (EPA) and other agencies. The EPA has established an acceptable risk range of 1 in 1 million to 1 in 10,000 (EPA 1990).

To put this risk range in context, it is estimated that about one in three Americans will develop cancer during their lifetime from all sources (American Cancer Society 1992), and that the risk of developing cancer from exposure to radiation naturally present in the environment (primarily radon) is about 1 in 100 (EPA 1989). Thus, the acceptable range is a very small percentage of the cancer risk expected in the general U.S. population from everyday exposures. For example, the incremental risk at the upper end of the EPA's range means that if all persons in a population of 10,000 were assumed to be repeatedly exposed to site contaminants, one additional person might get cancer as a result of those exposures compared with the estimated 3,000 cancer cases expected from all other exposures; that is, the number of persons who would be expected to develop cancer in that population would be 3,001 rather than 3,000 .

Potential health effects other than cancer that could result from exposure to chemical contaminants were also assessed. The quantitative measure of noncarcinogenic health effects is the hazard index. The EPA has defined a hazard index of greater than 1 as indicating possible adverse noncarcinogenic health effects.

1 The assessment presented in the BRA (DOE and DA 1997a) also included risk estimates for a hypothetical future resident exposed to groundwater contaminants. These estimates indicate potential risks from three wells to be slightly higher than 1 in 10,000 (for a hypothetical future resident) and to be primarily attributable to TCE. Under the residential scenario, the hazard indices for several wells containing nitroaromatic compounds and nitrate also exceed 1. 
TABLE 1 Summary of Human Health Risk Assessment Results for the Groundwater Operable Unit ${ }^{\mathrm{a}}$

Carcinogenic Risk

\begin{tabular}{llll}
\multicolumn{1}{c}{ Scenario } & Chemical & Radiological & Hazard Index \\
\hline $\begin{array}{l}\text { Current and foreseeable } \\
\text { future recreational } \\
\text { visitor }\end{array}$ & $2 \times 10^{-10}$ to $3 \times 10^{-7 \mathrm{~b}}$ & $4 \times 10^{-9}$ to $2 \times 10^{-6 \mathrm{~b}}$ & $<0.001$ to $0.2^{\mathrm{b}}$ \\
$\begin{array}{l}\text { Hypothetical resident } \\
\text { Hyon }\end{array}$ & $6 \times 10^{-7}$ to $1 \times 10^{-3 \mathrm{c}}$ & $1 \times 10^{-7}$ to $7 \times 10^{-5 \mathrm{~d}}$ & 0.003 to $40^{\mathrm{c}}$ \\
\hline
\end{tabular}

a Information presented in this table is taken from the BRA (DOE and DA 1997a). Current and foreseeable future land use were assumed to be recreational. Estimates for the current and foreseeable future recreational visitor scenario were performed for the springs only; there is no access to the groundwater under this scenario, consistent with actual site conditions. The estimates for the hypothetical resident scenario were calculated for informational purposes and assumed access to groundwater for ingestion, although currently no such access exists.

b The range shown represents estimates for 15 springs for the recreational visitor scenario.

c The range shown represents estimates for 38 of 86 monitoring wells at the chemical plant area. Estimates were not obtained for the remaining 48 wells because no levels of any carcinogenic chemical compound were detected. The upper end of this range is reported for well MW-2038, due primarily to the TCE reported. The most recent data obtained from this well, however, indicate lower concentrations, thus resulting in a lower estimate for this well (i.e., at $10^{-4}$ ).

d The range shown represents estimates for 68 of 86 monitoring wells at the chemical plant area. Samples were not collected for the remaining 18 monitoring wells during the joint DOE and DA sampling rounds conducted in 1995. These wells had been reported as nondetects in sampling rounds previous to 1995 . The estimates represent the potential risk for the hypothetical resident scenario for the ingestion of uranium in groundwater. The hypothetical resident scenario assumed access to groundwater for ingestion, although currently no such access exists.

e The range shown represents estimates for 69 of 86 monitoring wells. Data from the remaining 17 monitoring wells were reported as nondetects. 
The most likely receptor for site-related groundwater contamination is a recreational visitor to the area. The assessment assumed conservatively that for 30 years the recreational visitor would visit the area 20 times a year for 4 hours each visit and each time ingest or drink 2 cups of springwater. The human health risk assessment concluded that a recreational visitor ingesting springwater from any of the 15 springs evaluated was not at risk for cancer or systemic toxicity; these results are expected to be representative of all springs in the study area. The recreational visitor was assumed not to have any exposure to the contaminated groundwater itself. This assumption is consistent with land use conditions at the chemical plant, where a recreational visitor would not have direct access to the groundwater. The risk of developing radiation-induced cancer was estimated to range from 4 in 1 billion to 2 in 1 million. These values are low and well within the acceptable risk range of 1 in 1 million to 1 in 10,000 recommended by the EPA (EPA 1989). The estimated risk for developing chemical-induced cancer is similarly low and ranges from 2 in 10 billion to 3 in 10 million. The hazard indices estimated for a recreational visitor at the springs ranged from less than 0.001 to 0.2 .

\subsection{ECOLOGICAL ASSESSMENT}

The results of the ecological assessment indicate that contaminant concentrations in springwater and sediment pose little or no risk to ecological resources of the area, and that remediation from an ecological perspective is not needed.

Biotic surveys of macroinvertebrates, fish, and amphibians that inhabit the Burgermeister Spring drainage indicated no evidence of adverse effects. The spring was determined to contain generally good aquatic habitat, and the species present are typical of those found in similar habitats throughout the Midwest. Although the fish community was limited in diversity and the macroinvertebrate community was categorized as slightly impaired, the communities are likely affected by the physical nature of the spring and its drainage rather than by contaminant levels. Flow in the uppermost portion of Burgermeister Spring is maintained by groundwater discharge at the spring. Under low-flow conditions, as commonly occur in the summer, the stream drainage below the spring becomes intermittent, and portions of the habitat become dry. Surveys of amphibians found a community typical of similar habitats in the Midwest.

The results of toxicity testing of surface water and sediment indicate the potential for some toxicity to fish and macroinvertebrates from within Burgermeister Spring proper, but not downstream of the spring. However, the presence of apparently unaffected macroinvertebrate, fish, and amphibian communities in these locations suggests that local populations are tolerant of (or have adapted to) the contaminant levels present in surface water and sediment in the Burgermeister Spring drainage. Tissue analyses revealed relatively low levels of contaminant bioconcentration, all below levels of concern. 
Modeling of contaminant uptake by the white-tailed deer and American robin drinking from Burgermeister Spring predicted very low levels of contaminant uptake by these species. No risk of harm was found to be caused by the modeled contaminant doses to land-based plants and animals drinking from Burgermeister Spring or other springs in the area.

Risk estimates for aquatic biota based on media concentrations indicate that surface water concentrations of iron, manganese, mercury, uranium, 1,3,5-TNB, and 2,4,6-TNT, and sediment concentrations of arsenic, lead, and silver might pose low to moderate risks to aquatic biota. However, the aquatic community in Burgermeister Spring is typical of similar habitats elsewhere in the Midwest and does not appear to be adversely affected by contaminant concentrations at this time. Few of the other springs in the area provide suitable habitat on the basis of their inherent or natural features, and, at best, support only very limited aquatic communities.

\subsection{REMEDIATION GOALS FOR THE CHEMICAL PLANT GROUNDWATER}

The evaluations presented in the RI (DOE and DA 1997b) and the BRA (DOE and DA 1997a) indicate that current contaminant concentrations in chemical plant area groundwater do not pose unacceptable risk to the recreational visitor because there is no access to the groundwater under this scenario. In addition, contaminant concentrations at the surface springs are low and likewise do not pose unacceptable risk to the recreational visitor. Current and likely foreseeable future land use at the chemical plant area is considered to be recreational.

However, the groundwater at the chemical plant area is considered potentially useable (EPA 1986; MK-Ferguson 1990); therefore, consistent with EPA guidelines, restoration of this groundwater to beneficial use may be considered. In recognition of this, alternatives that could reduce or remove contaminants, such as TCE and nitrate, were evaluated in addition to those that provide verification of decreasing groundwater contaminant concentrations due to source removals stipulated in the chemical plant ROD (DOE 1993).

The remediation goal for the chemical plant area GWOU is to verify decreasing groundwater contaminant concentrations that are expected to result from the source removals and to improve and restore groundwater conditions as much as technically practicable. 


\section{SCREENING OF PRELIMINARY ALTERNATIVES}

\subsection{PRELIMINARY ALTERNATIVES CONSIDERED}

The alternatives discussed in this chapter were considered in the FS (DOE and DA 1998) in the context of follow-on activities after source removal and source control response actions have been implemented at the chemical plant area. These source removals are stipulated in the ROD (DOE 1993) addressing soil and structural contamination at the chemical plant area.

In the development of preliminary alternatives, a broad range of remediation technologies, both in-situ and ex-situ, were considered for application at the chemical plant area to address the contaminated groundwater. In-situ technologies considered included containment approaches such as barrier walls or immobilization methods and in-situ treatment approaches such as natural processes or newer innovative technologies such as electrokinetics, phytoremediation, Fenton-like reagents, and treatment walls. Groundwater removal technologies, including conventional and nonconventional well extraction, interceptor trenches, and excavation, were considered if treatment was to be performed ex-situ. Conventional and newer innovative technologies for ex-situ groundwater treatment using physical, chemical, and biological methods were evaluated. From these technologies, nine broad alternatives were developed in the FS (DOE and DA 1998) that are protective of human health and the environment, that maintain protection over time, and that minimize untreated waste. The nine broad alternatives outlined below ranged from those that could provide a comprehensive restoration of the groundwater to those that were more limited in scope and focused on localized areas. The selected remedial strategy may incorporate the most promising components of multiple alternatives considered in the preliminary alternative analysis.

To further facilitate the FS (DOE and DA 1998) evaluations, the concentrations reported for 1997 to 1998 for each well for the contaminants of concern were reviewed, and concentrations that exceeded established bench marks were plotted on a map of the chemical plant area (Figure 6). The bench marks used were $5 \mu \mathrm{g} / \mathrm{L}$ for TCE and $10 \mathrm{mg} / \mathrm{L}$ for nitrate, which were established with reference to the maximum contaminant levels (MCLs) for those substances. A bench mark of $0.11 \mu \mathrm{g} / \mathrm{L}$ was used for 2,4-DNT, which was established with reference to the Missouri Water Quality standard. Risk-based concentrations of $0.13,2.8$, and $1.8 \mu \mathrm{g} / \mathrm{L}$ were calculated as bench marks for 2,6-DNT, 2,4,6-DNT, and 1,3,5-TNB, respectively. These concentrations are either equivalent to the $10^{-6}$ risk or the hazard index of 1 for the hypothetical resident scenario. The EPA's proposed MCL of $20 \mu \mathrm{g} / \mathrm{L}$ for uranium was used as the bench mark for uranium. The $20 \mu \mathrm{g} / \mathrm{L}$ is equivalent to $14 \mathrm{pCi} / \mathrm{L}$, on the basis of the uranium isotopic ratio determined in groundwater at the chemical plant area.

From this map, seven zones of contamination are indicated. These zones were derived from the locations of wells in which measured contaminant concentrations exceeded their respective 


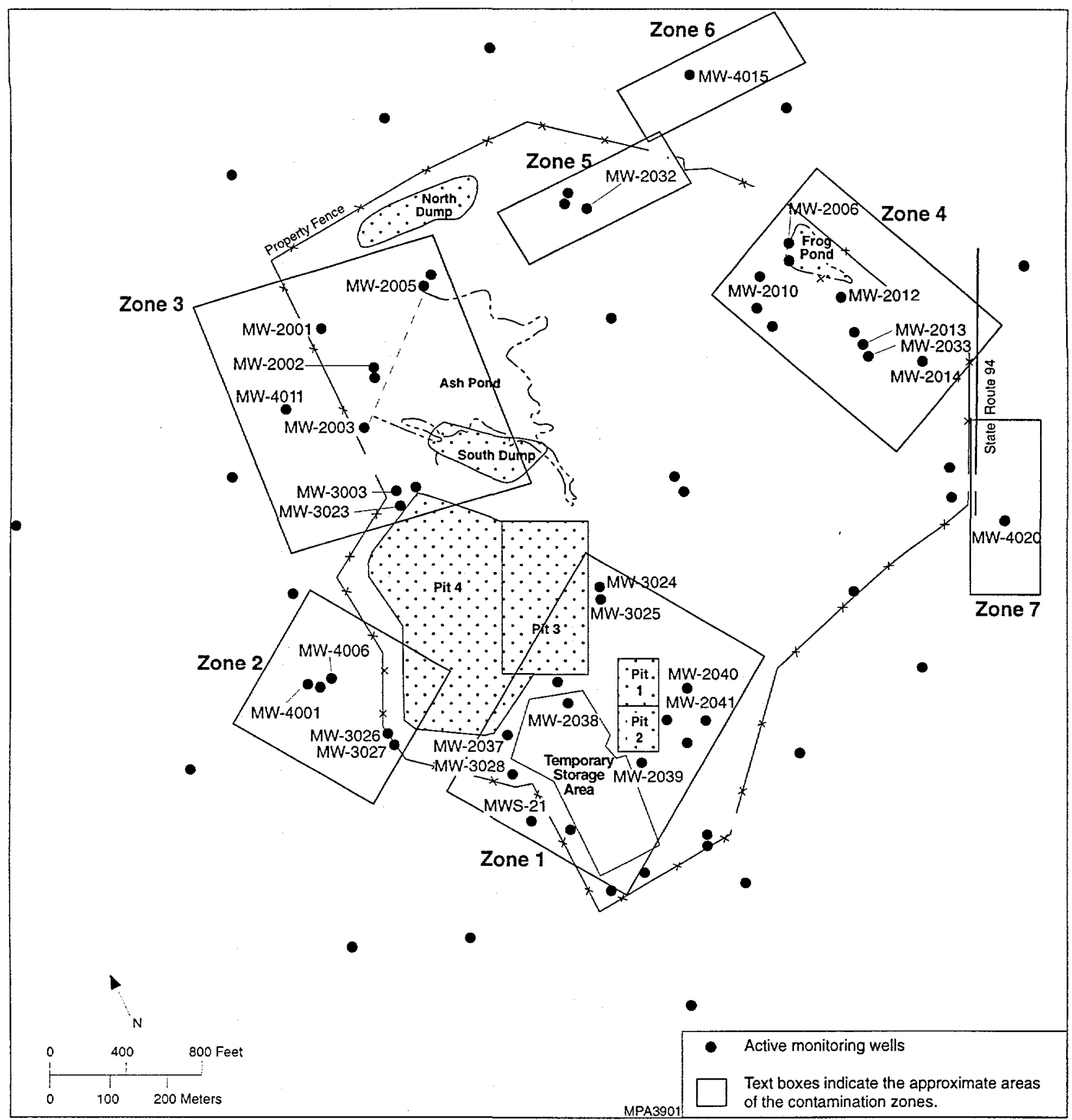

FIGURE 6 Contamination Zones at the Weldon Spring Chemical Plant Area 
bench marks and the inferred direction of groundwater flow based on the potentiometric surface of the shallow groundwater system beneath the chemical plant area.

Seven zones were used to define the area of groundwater contamination at the chemical plant area that would require cleanup. Each zone was drawn in the shape of a rectangle. The size of each rectangle was chosen such that it included all of the wells in which the maximum measured contaminant concentrations exceeded established bench marks. In addition, each rectangle included some buffer space to account for potential contamination in areas where there were no wells. The rectangles were oriented parallel with the local direction of ground water flow. Within each rectangle, the concentration of each contaminant was assumed to be a constant value. In general, this value was equal to the maximum contaminant concentration for all wells within the area that had concentrations that exceeded the established bench marks. This procedure thus provided a range of constant concentrations for each zone. This range was then used to estimate a maximum and minimum cleanup time for each contaminant within a zone. In a few cases, the constant concentration was obtained from a single well measurement. For these cases, only one value was used, and there was no range.

Alternative 1: No Action Alternative. CERCLA regulations require that this alternative be considered. It is intended to provide a baseline against which other alternatives can be compared. No further action would be taken at the site under the no action alternative, and any existing, ongoing maintenance, monitoring, and remedial actions associated with the groundwater would be discontinued. Although contaminant concentrations are expected to decrease with time as a result of source removals at the chemical plant area, no monitoring data would be available to verify this occurrence.

Alternative 2: Long-Term Monitoring. This alternative involves routine sampling and analysis to provide monitoring data that would verify expected decreasing contaminant concentrations. Under this alternative, lower contaminant concentrations are expected in the future because natural processes will continue to occur.

Alternative 3: Monitored Natural Attenuation (MNA). This alternative includes the construction of new monitoring wells and the implementation of a sampling and analysis scheme that is more elaborate than that required under Alternative 2 to verify and monitor parameters that would document the natural remediation processes. The term "monitored natural attenuation" as used in the EPA Directive "Use of Monitored Natural Attenuation at Superfund, RCRA Corrective Action, and Underground Storage Tank Sites" (EPA 1999), refers to the reliance on natural attenuation processes (within the context of a carefully controlled and monitored site cleanup approach) to achieve site-specific remediation objectives within a time frame that is reasonable compared with that offered by other more active methods. The "natural attenuation processes" that are at work in such a remediation approach include a variety of physical, chemical, or biological processes that, 
TABLE 2 Contaminants of Concern for Zones at the Chemical Plant Area

\begin{tabular}{|c|c|c|c|c|c|c|c|c|}
\hline \multirow[b]{2}{*}{ Zone } & \multirow[b]{2}{*}{$\begin{array}{c}\text { Monitoring Wells } \\
\text { with Contaminants } \\
\text { Exceeding Bench Marks }\end{array}$} & \multicolumn{7}{|c|}{ Range of Maximum Contaminant Concentration } \\
\hline & & $\begin{array}{c}\text { TCE } \\
(\mu \mathrm{g} / \mathrm{L}) \\
\end{array}$ & $\begin{array}{l}\text { Uranium } \\
(\mathrm{pCi} / \mathrm{L})\end{array}$ & $\begin{array}{l}\text { Nitrate } \\
(\mathrm{mg} / \mathrm{L})\end{array}$ & $\begin{array}{c}2,4-\mathrm{DNT} \\
(\mu \mathrm{g} / \mathrm{L})\end{array}$ & $\begin{array}{c}2,6-\mathrm{DNT} \\
(\mu \mathrm{g} / \mathrm{L})\end{array}$ & $\begin{array}{c}2,4,6-\mathrm{TNT} \\
(\mu \mathrm{g} / \mathrm{L})\end{array}$ & $\begin{array}{c}1,3,5-\mathrm{TNB} \\
(\mu \mathrm{g} / \mathrm{L})\end{array}$ \\
\hline 1 & $\begin{array}{l}\text { MW-2037, MW-2038 } \\
\text { MW-2039, MW-2039 } \\
\text { MW-2040, MW-2041 } \\
\text { MW-3024, MW-3025 } \\
\text { MWS-21 }\end{array}$ & $52-1,400$ & 55 & $88-1,000$ & $0.73-1.4$ & $0.24-0.27$ & $\mathrm{NA}^{\mathrm{a}}$ & NA \\
\hline 2 & $\begin{array}{l}\text { MW-3026, MW-3027 } \\
\text { MW-4001, MW-4006 }\end{array}$ & 5.5 & NA & $23-450$ & 0.13 & $2.3-2.5$ & $\mathrm{NA}$ & $21-62$ \\
\hline 3 & $\begin{array}{l}\text { MW-2001, MW-2002 } \\
\text { MW-2003, MW-2005 } \\
\text { MW-3003, MW-3023 } \\
\text { MW-4011 }\end{array}$ & NA & $15-22$ & $80-420$ & $0.12-0.73$ & $0.19-2.4$ & $\mathrm{NA}$ & NA \\
\hline 4 & $\begin{array}{l}M W-2006, M W-2010 \\
M W-2012, M W-2013 \\
M W-2014, M W-2033\end{array}$ & NA & NA & NA & $0.12-6.0$ & $0.50-110$ & 25 & $2.8-7.2$ \\
\hline 5 & $\mathrm{MW}-2032$ & NA & NA & 110 & NA & 1.3 & 4.4 & 2.0 \\
\hline 6 & MW-4015 & $\mathrm{NA}$ & NA & NA & NA & 0.83 & NA & 7.1 \\
\hline 7 & MW-4020 & NA & 20 & NA & NA & NA & $\mathrm{NA}$ & NA \\
\hline
\end{tabular}

a NA denotes that the particular contaminant of concern was not detected, or that the reported concentration did not exceed the respective bench mark. 
under favorable conditions, act without human intervention to reduce the mass, toxicity, mobility, volume, or concentration of contaminants in soil or groundwater. These in-situ processes include biodegradation; dispersion; dilution; sorption; volatilization; radioactive decay; and chemical or biological stabilization, transformation, or destruction of contaminants. The implementation of this alternative may require advanced groundwater modeling capabilities.

\section{Alternative 4: Groundwater Removal and On-Site Treatment Using Granular Activated} Carbon and Ion Exchange. This alternative involves using conventional vertical extraction wells to remove contaminated groundwater, pumping and treating the groundwater at an aboveground treatment system, and releasing or managing the treated groundwater consistent with CERCLA and overall site strategies. Adsorption by granular activated carbon (GAC), which is a well-developed, effective, and widely applied technology, would be used to remove organic materials, including nitroaromatic compounds (such as 2,4-DNT and TNT) and TCE by chemically and physically binding them to the carbon.

\section{Alternative 5: Groundwater Removal, On-Site Treatment Using Ultraviolet Oxidation.} Similar to Alternative 4, this alternative involves extraction and treatment of contaminated groundwater. Ultraviolet oxidation is a relatively new treatment technology that can be effective for water contaminated with TCE and nitroaromatic compounds. Unlike adsorption on GAC material, it destroys the compounds rather than simply transferring them to a more easily disposable medium.

Alternative 6: Groundwater Removal, On-Site Treatment Using Phytoremediation. The objectives and design of Alternative 6 are similar to those of Alternatives 4 and 5, except that this alternative assumes on-site treatment using phytoremediation. Phytoremediation is the use of plants to remediate contaminated groundwater. It exploits an enzymatic activity occurring in plants at the root level and has been shown to be effective in a number of studies. Contaminated groundwater would be removed by using conventional vertical extraction wells and pumped to and treated at an aboveground constructed wetland. A constructed wetland is a lined, man-made lagoon that contains a variety of plants that accumulate and remove nitroaromatic compounds and other contaminants from influent waters. The treated groundwater would be managed consistent with overall site strategies.

Alternative 7: Removal and On-Site Treatment of Groundwater in Zones 1 and 2. This alternative involves extraction and on-site treatment of contaminated groundwater in Zones 1 and 2 near the raffinate pits area. These two zones are characterized primarily by TCE contamination. This alternative provides for active remediation of groundwater in Zones 1 and 2 only.

The objectives and design of Alternative 7 are similar to those for Alternative 4, except that contaminated groundwater only in Zones 1 and 2 would be removed and treated under this alternative. This groundwater would be removed by using conventional wells, pumped to and treated 
in an aboveground treatment system consisting of a sequence of physical and chemical unit operations, and released at a discharge point.

Alternative 8: In-Situ Treatment of TCE Using In-Well Vapor Stripping. In-well vapor stripping technology involves the creation of a groundwater circulation pattern and simultaneous aeration within the vapor stripping well to volatilize the TCE from the circulating groundwater. This process would not be amenable to removal of nonvolatile or highly soluble compounds like nitrates and nitroaromatic compounds that may also be present. Air-lift pumping is used to lift groundwater and strip it of contaminants. Contaminated vapors are drawn off for aboveground treatment. Partially treated groundwater is forced out of the well into the vadose zone where it reinfiltrates to the water table. Untreated groundwater enters the well at its base, thereby replacing the water lifted through pumping. Eventually, the partially treated water is cycled back through the well via this process until it is fully treated.

Alternative 9: In-Situ Chemical Oxidation of TCE Using Fenton-Like Reagents. This alternative involves in-situ chemical oxidation of TCE-contaminated groundwater in Zones 1 and 2 with Fenton-like reagents. This alternative provides for active remediation of TCE only.

This in-situ treatment process would involve the direct sequential injection into the shallow bedrock aquifer of aqueous solutions of hydrogen peroxide, a ferrous compound, and acidic solutions (e.g., acetic acid). Acetic acid would be introduced beforehand to establish acidic conditions conducive to production of hydroxyl radicals by the Fenton-like reagents. The generated hydroxyl radicals would react with the TCE in the groundwater to form mostly carbon dioxide $\left(\mathrm{CO}_{2}\right)$ and water.

\subsection{ALTERNATIVES ELIMINATED FROM CONSIDERATION}

Alternatives 1 through 9 were evaluated in the FS (DOE and DA 1998) in terms of the three screening criteria defined in the National Oil and Hazardous Substances Pollution Contingency Plan (NCP) (EPA 1990)-effectiveness, implementability, and cost. On the basis of this screening process, Alternatives 5 and 6 were not retained for further consideration. Although the theoretical effectiveness of these alternatives is similar to other alternatives that have been retained, the treatment technology is more uncertain and is not well established. 


\subsection{ALTERNATIVES RETAINED FOR FURTHER EVALUATION}

On the basis of the screening process, the following alternatives were retained for detailed evaluation:

- Alternative 1: No Action,

- Alternative 2: Long-Term Monitoring,

- Alternative 3: Monitored Natural Attenuation,

- Alternative 4: Groundwater Removal and On-Site Treatment Using GAC and Ion Exchange,

- Alternative 7: Removal and On-Site Treatment of Groundwater in Zones 1 and 2 ,

- Alternative 8: In-Situ Treatment of TCE Using In-Well Vapor Stripping, and

- Alternative 9: In-Situ Chemical Oxidation of TCE Using Fenton-Like Reagents. 


\section{DESCRIPTION AND ANALYSIS OF FINAL ALTERNATIVES}

\subsection{DESCRIPTION OF FINAL ALTERNATIVES}

Seven of nine preliminary alternatives were retained for detailed analysis in the FS (DOE and DA 1998) and are summarized in this chapter. As stated earlier, these alternatives are being considered in the context of follow-on activities after source removal and control response actions have been implemented at the chemical plant area (DOE 1993).

\subsubsection{Alternative 1: No Action}

This alternative is used as a baseline against which to compare the other alternatives being considered. Under the no action alternative, groundwater at the chemical plant area would remain "as is." No containment, removal, treatment, or other mitigating actions would be implemented. The no action alternative does not include groundwater monitoring or any other active or passive institutional controls that may reduce any potential for human exposure (e.g., land use restrictions). Under Alternative 1, it is assumed that all current activities, including groundwater monitoring by DOE, would be discontinued. Contaminant concentrations are expected to decrease as a result of natural processes that will continue to occur and from current source removals being conducted per the chemical plant ROD (DOE 1993). However, monitoring would not be performed to verify the decrease in contaminant concentrations.

\subsubsection{Alternative 2: Long-Term Monitoring}

Under Alternative 2, no active remediation would take place; however, long-term monitoring of the groundwater would be performed. The concentrations of contaminants in groundwater at the chemical plant area are expected to decrease with time. This decrease is expected to result from source removals and dilution from infiltration of rainwater and runoff. Further evaluation through long-term monitoring and associated activities would verify whether these processes decreased contaminant levels.

Groundwater monitoring would be conducted by using the existing monitoring well network. It is possible that this network would be expanded or reduced on the basis of subsequent design of an optimal network. Monitoring would be performed for an appropriate period of time that would be defined in the remedial design/remedial action (RD/RA) phase. As required by CERCLA, a review would be conducted every five years because contaminants would remain in site groundwater at levels above those that allow for unlimited use and unrestricted exposure. 


\subsubsection{Alternative 3: Monitored Natural Attenuation}

This alternative involves the use of monitoring to verify the effectiveness of naturally occurring processes in the GWOU to reduce contaminant concentrations. Dilution and dispersion are the primary natural processes identified that are acting to reduce all contaminant concentrations in groundwater at the chemical plant area (DOE 1999). However, because of the wide range in hydraulic conductivities and the karst nature of the aquifer across the contaminated areas, it is difficult to predict with any certainty the remedial time frame once source-removal actions have been completed. The evaluation presented in the Supplemental FS (DOE 1999) indicates a long time period (in the order of decades) before contaminant concentrations would decrease to the bench marks that are equivalent to MCLs or risk-based concentrations. Table 3 presents the results of these calculations.

The source removals that are performed per the chemical plant ROD (DOE 1993) are expected to ultimately result in decreasing groundwater contaminant levels, since no further contribution to the contamination will occur. Conditions do not appear to be favorable for biological processes degrading the TCE, nitroaromatic compounds, or nitrate; however, sorption of uranium is expected to be occurring to some extent. In addition, discharged groundwater (to the surface springs, primarily Burgermeister Spring and the Southeast Drainage) are subject to further extensive dilution and physical and chemical degradation. Performance monitoring to determine continued occurrence of dilution and dispersion would be similar to that performed under Alternative 2. The monitoring activities would essentially be to verify contaminant concentration decreases at the various monitoring wells and discharge points (e.g., Burgermeister Spring).

As required by CERCLA, a review would be conducted every five years because contaminants would remain in site groundwater at levels above those that allow for unlimited use and unrestricted exposure.

\subsubsection{Alternative 4: Groundwater Removal and On-Site Treatment Using GAC and Ion Exchange}

This alternative involves using conventional vertical extraction wells to remove groundwater with contaminant levels exceeding the bench marks. In the evaluation presented in the Supplemental FS (DOE 1999), an estimated 24 vertical extraction wells would be required to address the contaminants at the chemical plant area to achieve a reasonable extraction rate and to provide wide enough coverage to prevent any bypass of contaminated groundwater. The evaluation presented in the Supplemental FS indicates a long time period (in the order of decades) before contaminant concentrations would decrease to bench marks that are equivalent to MCLs or risk-based concentrations. Table 3 presents the results of these calculations. It should be noted that the 
TABLE 3 Estimated Cleanup Times for Monitored Natural Attenuation and the Pump and Treat Method ${ }^{\mathrm{a}}$

\begin{tabular}{|c|c|c|c|c|c|c|c|c|}
\hline \multirow[b]{2}{*}{ Contaminants } & \multicolumn{2}{|c|}{ Zone 1} & \multicolumn{2}{|c|}{ Zone 2} & \multicolumn{2}{|c|}{ Zone 3} & \multicolumn{2}{|c|}{ Zone 4} \\
\hline & MNA & $\begin{array}{c}\text { Pump and } \\
\text { Treat }\end{array}$ & MNA & $\begin{array}{c}\text { Pump and } \\
\text { Treat }\end{array}$ & MNA & $\begin{array}{c}\text { Pump and } \\
\text { Treat }\end{array}$ & MNA & $\begin{array}{c}\text { Pump and } \\
\text { Treat }\end{array}$ \\
\hline TCE & $61-145$ & $30-71$ & 14 & 7 & NA & NA & NA & NA \\
\hline Uranium & 395 & 194 & NA & $\mathrm{NA}$ & $2,400-15,460$ & $995-6,425$ & NA & NA \\
\hline Nitrate & $80-169$ & $39-83$ & $149-685$ & $72-330$ & $9,040-16,220$ & $3,755-6,740$ & NA & $\mathrm{NA}$ \\
\hline 2,4-DNT & $84-112$ & $41-55$ & 36 & 18 & $435-9,910$ & $180-4,100$ & $10-480$ & $5-229$ \\
\hline 2,6-DNT & $50-59$ & $24-29$ & $1,140-1,172$ & $550-570$ & $3,600-27,980$ & $1,490-11,630$ & $300-1,480$ & $142-710$ \\
\hline $2,4,6-\mathrm{TNT}$ & $N A^{b}$ & NA & $\mathrm{NA}$ & NA & NA & NA & 602 & 287 \\
\hline $1,3,5-\mathrm{TNB}$ & $\mathrm{NA}$ & NA & $212-302$ & $100-150$ & NA & $\mathrm{NA}$ & $20-190$ & $10-90$ \\
\hline \multirow[b]{2}{*}{ Contaminants } & \multicolumn{2}{|c|}{ Zone 5} & \multicolumn{2}{|c|}{ Zone 6} & \multicolumn{2}{|c|}{ Zone 7} & & \\
\hline & MNA & $\begin{array}{c}\text { Pump and } \\
\text { Treat }\end{array}$ & MNA & $\begin{array}{c}\text { Pump and } \\
\text { Treat }\end{array}$ & MNA & $\begin{array}{c}\text { Pump and } \\
\text { Treat }\end{array}$ & & \\
\hline TCE & NA & NA & NA & NA & NA & NA & & \\
\hline Uranium & NA & NA & NA & NA & 6,530 & 1,220 & & \\
\hline Nitrate & 3 & 9 & NA & NA & NA & NA & & \\
\hline 2,4-DNT & NA & NA & NA & NA & NA & NA & & \\
\hline 2,6-DNT & 7 & 20 & 7,600 & 2,240 & NA & $\mathrm{NA}$ & & \\
\hline 2,4,6-TNT & 0.4 & 1 & NA & NA & NA & NA & & \\
\hline $1,3,5-\mathrm{TNB}$ & 0.1 & 0.2 & 1,210 & 360 & $\mathrm{NA}$ & $\mathrm{NA}$ & & \\
\hline
\end{tabular}

a All values are in units of years. The ranges provided reflect the range of maximum concentrations for each of the contaminants within each zone (i.e., for zones that contain several monitoring wells).

b $\mathrm{NA}=$ not applicable because the contaminant was not reported in the particular zone at concentrations exceeding the bench mark. 
evaluations simulate ideal groundwater conditions and are not reflective of actual complex site conditions. The results provided represent the most optimistic performance under this alternative for ideal groundwater conditions; much poorer performance is expected under actual site conditions.

The extracted groundwater would be pumped and treated at an aboveground treatment system. Organic compounds such as TCE and 2,4-DNT would be removed by using the wellestablished GAC adsorption technology. Inorganic contaminants such as nitrate and uranium would be treated using ion exchange.

As required by CERCLA, a review would be conducted every five years because contaminants would remain in site groundwater at levels above those that allow for unlimited use and unrestricted exposure.

\subsubsection{Alternative 7: Removal and On-Site Treatment of Groundwater in Zones 1 and 2}

This alternative involves the extraction of TCE-contaminated groundwater in Zones 1 and 2, which are in the vicinity of the raffinate pits of the chemical plant area. In the evaluation presented in the Supplemental FS (DOE 1999), approximately 15 vertical extraction wells were estimated to be required to achieve a reasonable extraction rate and to provide wide enough coverage to prevent any bypass of the contaminants in Zones 1 and 2 .

As required by CERCLA, a review would be conducted every five years because contaminants would remain in site groundwater at levels above those that allow for unlimited use and unrestricted exposure.

\subsubsection{Alternative 8: In-Situ Treatment of TCE Using In-Well Vapor Stripping}

In-well vapor stripping technology involves the creation of a groundwater circulation pattern and simultaneous aeration within the vapor stripping well to volatilize the TCE from the circulating groundwater. This alternative is focused on remediating the TCE-contaminated groundwater in Zones 1 and 2 that has been identified near the raffinate pits area of the chemical plant area. Because of the nature of the technology involved, this alternative would not remediate the nitrate, nitroaromatic compounds, and uranium that may also be present.

The in-well vapor stripping technology consists primarily of a screened well submerged beneath the water table and an air line within the well extending to below the water table. A compressor delivers air or an inert gas such as nitrogen to the water column aerating the water within the well. The gas bubbles cause the water within the well to be less dense than the nonaerated water outside. As a result, the dense water flows in through the well screen and forces the aerated water 
upward within the well. The result is a rising column of aerated water within the well, which forms an air-lift pumping system.

As required by CERCLA, a review would be conducted every five years because contaminants would remain in site groundwater at levels above those that allow for unlimited use and unrestricted exposure.

\subsubsection{Alternative 9: In-Situ Chemical Oxidation of TCE Using Fenton-Like Reagents}

This alternative involves in-situ chemical oxidation of the TCE-contaminated groundwater that has been identified in Zones 1 and 2 of the chemical plant area. Because this technology has been proven to address organic compounds only, this alternative would primarily address TCE.

The application of this technology would consist of injecting aqueous solutions of hydrogen peroxide, ferrous sulfate $\left(\mathrm{FeSO}_{4}\right)$, and other chemicals (e.g., acetic acid) into the shallow bedrock aquifer through a series of injection wells. Preliminary engineering estimates indicate the installation of approximately two sets of nested application or injection wells, with multiple rounds (a minimum of two) of chemical reagent application.

As required by CERCLA, a review would be conducted every five years because contaminants would remain in site groundwater at levels above those that allow for unlimited use and unrestricted exposure.

\subsection{COMPARATIVE ANALYSIS OF FINAL ALTERNATIVES}

This section compares the seven final remedial action alternatives with regard to the nine CERCLA evaluation criteria. The nine evaluation criteria are categorized into the following three groups, as stipulated in the NCP (EPA 1990): threshold criteria, primary balancing criteria, and modifying criteria.

The threshold category contains the two criteria that an alternative must meet in order to be eligible for selection:

- Overall protection of human health and the environment and

- Compliance with applicable or relevant and appropriate requirements (ARARs), unless a waiver condition applies. 
These threshold criteria ensure that the remedial action selected will be protective of human health and the environment and that the action will attain the ARARs identified at the time of the ROD or provide grounds for invoking a waiver.

The primary balancing category contains the five criteria that are used to assess the relative advantages and disadvantages of each alternative:

- Long-term effectiveness and permanence;

- Reduction of toxicity, mobility, or volume through treatment;

- Short-term effectiveness;

- Implementability; and

- Cost.

Cost-effectiveness is determined by evaluating three of the five balancing criteria: long-term effectiveness and permanence; reduction of toxicity, mobility, or volume through treatment; and short-term effectiveness. Overall effectiveness is then compared with cost to ensure that the costs are proportional to the overall effectiveness of a remedial action.

The modifying category consists of:

- State acceptance and

- Community acceptance.

These two modifying criteria will be addressed in the responsiveness summary and ROD that will be prepared following the public comment period for this Proposed Plan; therefore, they are not addressed in this analysis. The results of the comparative analysis performed for the final alternatives on the basis of the first seven criteria are summarized in Table 4 .

\subsubsection{Overall Protection of Human Health and the Environment}

The no action alternative should be adequately protective of human health and the environment over the long term. However, monitoring would not be performed to verify contaminant concentrations. Under current recreational land use conditions, the contaminated groundwater at the chemical plant area poses no imminent risk to human health or the environment. Currently, the groundwater is not accessible and is not used at the site. Land use in the foreseeable future (i.e., the 
Alternative 2: Long-Term Monitoring

Overall protection of human health and the environment

Compliance with ARARs

Long-term effectiveness and permanence
Like all of the alternatives, would be adequately protective of human health and the environment, although monitoring data would not be available to verify this occurrence.

Calculations indicate a time period of at least several decades to approach ARARs.

Is expected to afford long-term effectiveness and permanence, although investigative and monitoring activities would not be performed.
Like all of the alternatives, would be adequately protective of human health and the environment. Monitoring data would be collected to verify that conditions continued to be protective of human health and the environment.

Calculations indicate a time period of at least several decades to approach ARARs.

Provides for long-term effectiveness and permanence; unlike Alternative 1, would provide verification monitoring of the groundwater within the operable unit.
Reduction of toxicity, mobility, or volume through treatment
No reduction of toxicity, mobility, or volume through treatment would be accomplished because the contaminated groundwater would not be treated.
No reduction of toxicity, mobility, or volume through treatment would be accomplished because the contaminated groundwater would not be treated.
Alternative 3: Monitored N Attenuation

Like all of the alternatives, would be adequately protec of human health and the environment. Monitoring $\mathrm{d}$ would be collected to verify conditions continued to be protective of human health the environment.

Calculations indicate a time period of at least several de to approach ARARs.

Provides for long-term effectiveness and permane Verification monitoring dat would be collected.

No reduction of toxicity, mobility, or volume throug treatment would be accomplished because the contaminated groundwater would not be treated. 
Alternative 4: Groundwater Removal and On-Site Treatment Using GAC and Ion Exchange

Like all of the alternatives, would be adequately protective of human health and the
Alternative 7: Removal and OnSite Treatment of Groundwater in Zones 1 and 2
Alternative 8: In-Situ Treatment of TCE Using In-Well Vapor Stripping
Alternative 9: In-Situ Chemical Oxidation of TCE Using FentonLike Reagents ta environment.

ive
Calculations indicate that it could take several decades to approach ARARs due to the complex hydrogeologic characteristics of the site and the state of current technology. A relatively shorter time period to approach ARARs than Alternative 3.

Affords long-term effectiveness and permanence because contaminant concentrations would be removed or reduced through extraction and treatment.

Reduction of the toxicity, mobility, or volume associated with all groundwater contamination within the shallow bedrock aquifer would be accomplished upon successful implementation of this alternative.
Like all of the alternatives, would be adequately protective of human health and the environment.
Like all of the alternatives, would be adequately protective of human health and the environment.
Like all of the alternatives, would be adequately protective of human health and the environment.
Calculations indicate that it could take several decades to approach ARARs due to complex hydrogeologic characteristics of the site and the state of current technology. The ARAR for TCE could be approached in a similar amount of time as Alternative 4, but longer than Alternatives 8 and 9. ARARs for nitrate and 2,4-DNT would be approached in Zones 1 and 2 in a time period similar to that in Alternative 4.

Would reduce concentrations of TCE, nitrate, nitroaromatic compounds, and uranium present in Zones 1 and 2. Natural processes and source removals per the chemical plant ROD (DOE 1993) are expected to result in decreases of contaminant levels in the remaining zones.

Reduction of the toxicity, mobility, or volume associated with TCE, nitrate, nitroaromatic compounds, and uranium in Zones 1 and 2 would be accomplished upon successful implementation of this alternative.
Complies with the ARAR for TCE in a shorter period of time than Alternative 7 and in a slightly longer period of time than Alternative 9. The ability to approach the ARAR is also limited by the complex hydrogeologic characteristics of the site and the state of current technology.

TCE in Zones 1 and 2 would be reduced or removed by treatment of groundwater. Natural processes and source removals per the chemical plant ROD (DOE 1993) are expected to result in decreases of contaminant levels in the remaining zones.

Reduction of the toxicity, mobility, or volume associated with TCE contamination at the chemical plant area (Zones 1 and 2) would be accomplished upon successful implementation of this alternative.
Requires the least time to comply with ARARs for TCE as compared with all other alternatives, including Alternatives 7 and 8 . The ability to approach the ARAR is also limited by the complex hydrogeologic characteristics of the site and the state of current technology.
TCE in Zones 1 and 2 would be reduced or removed. Natural processes and source removals per the chemical plant ROD (DOE 1993) are expected to result in decreases of contaminant levels in the remaining zones.

Reduction of the toxicity, mobility, or volume associated with TCE contamination at the chemical plant area (Zones 1 and 2) would be accomplished upon successful implementation of this alternative. 
TABLE 4 (Cont.)

Alternative 1: No Action

Alternative 2: Long-Term Monitoring

No potential impacts on workers or the environment because no activities would be undertaken.

\section{Short-term effectiveness}

Implementability
No implementability concerns because no action would be taken nor would any future activities be considered.

Lowest future cost.
Potential impacts are expected to be low, with less than one case of occupational injury and no occupational fatalities during proposed monitoring well construction. Any potential short-term environmental impacts would be limited to the immediate vicinity of the operable unit, and mitigative measures would be implemented to ensure minimal impacts to off-site areas.

Few implementability concerns because of the limited actions taken. Current monitoring operations would continue with the use of readily available resources.

Annual monitoring costs are estimated to be $\$ 0.4$ million, and capital costs are estimated to be $\$ 0.3$ million primarily for construction of additional wells.
Alternative 3: Monitored Natural Attenuation

The same as Alternative 2.

The same as Alternative 2 .

Capital costs of approximately $\$ 0.3$ million, primarily for construction of additional wells. The present-worth cost is estimated to range between $\$ 3$ million and $\$ 4$ million. 
Alternative 4: Groundwater Removal and On-Site Treatment Using GAC and Ion Exchange

Potential impacts associated with construction of the extraction wells. Construction activities are estimated to result in up to seven cases of occupational injury and less than one occupational fatality. Any potential short-term environmental impacts would be limited to the immediate vicinity of the operable unit, and mitigative measures would be applied to ensure minimal impacts to off-site areas.

Uncertainties with implementation of this alternative are associated with the need for location (or area)specific hydrogeologic data to verify the appropriateness of assumptions applied in the evaluations. Groundwater treatment technologies have been demonstrated at full-scale implementation for similar contaminants.

On the basis of an estimate of 24 extraction wells, capital costs are estimated to be approximately $\$ 7$ million, with the present-worth cost estimated to range between $\$ 15$ million and $\$ 24$ million.
Alternative 7: Removal and OnSite Treatment of Groundwater in Zones 1 and 2
Alternative 8: In-Situ Treatment of TCE Using In-Well Vapor Stripping

The same as Alternative 7.
Alternative 9: In-Situ Chemical Oxidation of TCE Using FentonLike Reagents
Expected to be low, with less than five cases of occupational injury and no occupational fatalities during operations and well construction activities. Any potential short-term environmental impacts would be limited to the immediate vicinity of the operable unit, and mitigative measures would be applied to ensure minimal impacts to off-site areas.

Uncertainties with implementation of this alternative are associated with the complex hydrogeologic characteristics of the site and the state of current technology. Specific hydrogeologic data indicate dewatering and very slow recovery of the aquifer as observed from the recent pump test performed in the area of Zones 1 and 2.

Capital costs are estimated to be approximately $\$ 5$ million, with the present-worth cost estimated to range between $\$ 14$ million and $\$ 20$ million. Provides some increases in protection via mass reduction in Zones 1 and 2 .
Uncertainties with implementation of this alternative are associated with the complex hydrogeologic characteristics of the site and the state of current technology. The generation of a vertical circulation pattern is expected to be difficult.

Capital costs are estimated to range between $\$ 1$ million and $\$ 3$ million. Annual costs are estimated to be $\$ 0.4$ million for monitoring.
The introduction of materials into Zones 1 and 2 was indicated by the pump test performed. The implementation of the technology for this alternative requires introducing a chemical reagent into the aquifer.
Lowest cost as compared with other TCE treatment alternatives (Alternatives 7 and 8); capital costs are estimated to be approximately $\$ 0.5$ million and include the material costs of the chemical reagents. Annual costs are estimated to be $\$ 0.4$ million and are associated with groundwater monitoring. This alternative provides an increase in protectiveness via mass reduction of TCE that is proportionate to the cost. 
next 30 years or so) would likely be similar to current land use. Groundwater contaminant levels are also expected to decrease with time as a result of source removals (DOE 1993) and naturally occurring processes that would further attenuate contaminant concentrations.

Alternatives 2 and 3 would also be adequately protective of human health and the environment over the long term. Potential migration of groundwater contamination toward the springs would be monitored. Monitoring data would be obtained to ensure continued protectiveness and to verify expectations for decreasing contaminant concentrations. Natural processes and source removals at the chemical plant (DOE 1993) are expected to attenuate contaminant concentrations in the long term; however, contaminant levels may increase during and immediately following source removal due to disturbances of the area generated by removal activities. Dilution of the contaminated groundwater with uncontaminated groundwater drawn from infiltration of rainwater and runoff could dilute the contaminant concentrations in groundwater and result in decreased concentrations.

Alternatives $4,7,8$, and 9 , if determined to be feasible and cost-effective, would be protective of human health and the environment because these alternatives would provide additional contaminant reduction or removal.

\subsubsection{Compliance with Potential ARARs}

Potential regulatory requirements that might be applicable or relevant and appropriate to the final remedial action alternatives are identified and evaluated in Appendix A of the FS (DOE and DA 1998).

Chemical-Specific ARARs. Chemical-specific ARARs (MCLs) have been identified for nitrate $(10 \mathrm{mg} / \mathrm{L}), \mathrm{TCE}(5 \mu \mathrm{g} / \mathrm{L})$, and three nitroaromatic compounds (nitrobenzene at $17 \mu \mathrm{g} / \mathrm{L}$, 2,4-DNT at $0.11 \mu \mathrm{g} / \mathrm{L}$, and 1,3-DNB at $1.0 \mu \mathrm{g} / \mathrm{L}$ ). The current levels of nitrate, TCE, and 2,4-DNT in groundwater at the chemical plant area exceed the respective chemical-specific ARARs. Groundwater levels of nitrobenzene and 1,3-DNB are below their respective ARARs.

Although all of the alternatives would meet chemical-specific ARARs at varying time frames, these time frames are in the order of at least several decades. Under no action, estimated decreases in concentrations for these contaminants are expected as a result of source removals being performed per the chemical plant ROD (DOE 1993). Natural processes that are occurring are likewise expected to continue and lower contaminant concentrations. Alternatives 2 and 3 would meet chemical-specific ARARs as a result of natural processes that would continue to occur and from source removals per the chemical plant ROD (DOE 1993). Monitoring data would be obtained to verify the expected decreases in contaminant concentrations. 
Alternative 4 would meet chemical-specific ARARs because groundwater extraction and treatment would be performed. Alternative 7 would meet chemical-specific ARARs as a result of groundwater extraction and treatment and from natural processes and source removals at the chemical plant (DOE 1993). Alternatives 8 and 9 would meet chemical-specific ARARs as a result of treatment and from natural processes and source removals at the chemical plant (DOE 1993).

Location-Specific ARARs. Location-specific ARARs are discussed in Appendix A of the FS (DOE and DA 1998). Location-specific ARARs would be similar for all alternatives. All alternatives would meet location-specific ARARs.

Action-Specific ARARs. Action-specific ARARs would vary, depending on the alternative or technology involved. Action-specific ARARs are discussed in Appendix A of the FS (DOE and DA 1998).

For the no action alternative, there would be no action-specific ARAR associated with this alternative because there would be no action taken. Alternatives 2, 3, 4, 7, 8, and 9 would meet substantive requirements related to any action-specific ARARs (e.g., construction, monitoring, extraction, injection wells, treatment plants, and discharge).

\subsubsection{Long-Term Effectiveness and Permanence}

For Alternative 1, under current recreational land use conditions, current contaminant concentrations of groundwater at the chemical plant area pose no unacceptable risk to human health or the environment. Although monitoring data would not be available for verification, the long-term effectiveness of this alternative is expected to be maintained by further decreases of contaminant concentrations as a result of natural processes and source removals at the chemical plant area currently being performed per the chemical plant ROD (DOE 1993). The compliance points for this operable unit would include the groundwater monitoring well network and the surface springs identified as known discharge points for the groundwater within this operable unit (e.g., Burgermeister Spring, Dardenne Creek, and Southeast Drainage).

Alternatives 2, 3, 7, 8, and 9 require monitoring and maintenance activities. For Alternatives 7,8 , and 9 , in addition to contaminant decreases resulting from natural processes and source removals per the chemical plant ROD (DOE 1993), some treatment would be performed for TCE. Monitoring data would be obtained to verify if reduction is permanent.

Implementation of institutional controls to enforce restrictions on water use may be necessary in conjunction with Alternatives 2,3,7,8, and 9. These restrictions could be enforced in the form of deed restrictions, well-drilling prohibitions, building permits, well use advisories, and deed notices. Current recreational land use of the site does not pose a threat to human health or the 
environment. However, institutional controls could be utilized to ensure that residential use of the groundwater would not occur. The effectiveness of institutional controls to be implemented and maintained for a long time period (i.e., greater than 30 years) may be uncertain.

Alternative 4 would reduce all contaminant concentrations through extraction and treatment and would afford long-term effectiveness and permanence because groundwater quality would essentially be restored.

\subsubsection{Reduction of Toxicity, Mobility, or Volume through Treatment}

Alternatives 1, 2, and 3 would not result in the reduction of toxicity, mobility, or volume through treatment because these alternatives do not provide for any treatment of the contaminated groundwater. Alternatives 7,8 , and 9 utilize treatment to reduce the toxicity, mobility, or volume associated with TCE contamination at the chemical plant area. Alternative 7 is focused on extracting and treating the TCE-contaminated area at the chemical plant area (i.e., Zones 1 and 2). Other contaminants present in these zones would also be extracted. The technologies involved in Alternative 8 target volatile organic compounds only, like TCE. The technology in Alternative 9 addresses all organic compounds, which means some treatment of nitroaromatic compounds in addition to TCE might also occur. Treatment under Alternative 4 is expected to reduce the toxicity, mobility, or volume associated with all contaminants in groundwater within the shallow bedrock aquifer.

\subsubsection{Short-Term Effectiveness}

For Alternative 1, there would be no short-term impacts to human health or the environment because no remedial action would be conducted. For Alternatives 2, 3, 7, and 9, construction activities are estimated to result in less than one case of occupational injury and no occupational fatalities (projections regarding installation of new wells were based on industry-specific statistics from the U.S. Bureau of Labor Statistics, as reported by the National Safety Council [1995]). Construction of vertical wells associated with Alternatives 4 and 7 are estimated to result in less than seven cases of occupational injury and less than one case of occupational fatality.

Some short-term impacts on recreational use of the surrounding wildlife areas might occur as the result of noise, exhaust fumes, and dust associated with possible monitoring well construction. Impacts to natural resources during construction of any new groundwater monitoring wells would be mitigated by avoiding unnecessary damage to vegetation, wildlife, and soil by controlling traffic and minimizing the areas of disturbance. 


\subsubsection{Implementability}

No concerns regarding implementability would be posed by Alternative 1, because no action would be taken. Few implementability concerns would be posed by Alternative 2 because of the limited actions taken. Site operations would continue using readily available resources for monitoring and maintaining institutional controls. Construction of any proposed monitoring wells would require mobilization of a drilling rig for installation.

Groundwater monitoring is readily implementable. Presently, numerous wells are located at the chemical plant area as part of the GWOU monitoring network of wells. Additional wells could be easily installed and monitored. Monitoring any off-site plume migration could easily be implemented.

The administrative feasibility of Alternatives 2 and 3 would be relatively straightforward. Weldon Spring Remedial Action Project (WSSRAP) and remedial action project activities are coordinated with the State of Missouri and EPA Region VII. That coordination would continue during implementation. The implementation of this alternative would not require coordination with any other agencies beyond that already occurring.

Institutional controls would be implemented under Alternatives 2, 3, 7, 8, and 9. Imposition of institutional controls on land under continued federal ownership (i.e., the area containing the on-site disposal cell and its footprint) would be relatively easy. Land use restrictions that could include St. Charles County zoning regulations and deed restrictions by the MDC may be necessary on land not currently under federal ownership (e.g., August A. Busch Memorial Conservation Area) to ensure long-term protectiveness. The implementability of appropriate institutional controls on nonfederal land may require agreement to be put in place between landowners and DOE. DOE has identified some options for enforcing water use restrictions that may be needed. It is currently in negotiations with the MDC to identify the appropriate and acceptable forms of institutional controls that could be implemented.

The implementability of the active remediation alternatives (Alternatives 4, 7, and 8) hinges on the ability to accurately identify the area-specific hydrogeologic characteristics of the aquifer. A pump and treat technology required for Alternatives 4 and 7 could not be implemented on a continuous basis because the aquifer dewatered during the pump test performed in the summer of 1998 , and it is still recovering after four months. The successful generation of a vertical circulation pattern needed for Alternative 8 was also not indicated. However, this same pump test indicated that introduction of materials into the aquifer in the TCE-contaminated area is possible. 


\subsubsection{Cost}

No net present-worth, capital, or annual operation and maintenance costs are associated with the no action alternative because no activities would be undertaken. Costs for Alternatives 2 and 3 are associated with continuing the existing environmental monitoring program and constructing and operating possible additional monitoring wells. Annual monitoring costs for Alternatives 2 and 3 are estimated to be approximately $\$ 0.4$ million; capital costs are estimated to be $\$ 0.3$ million.

Capital costs for Alternative 4 are estimated at approximately $\$ 7$ million; the 30 -year present-worth cost is estimated to range between $\$ 15$ million and $\$ 24$ million. Annual costs would be approximately $\$ 1$ million. This alternative is the most costly of the seven alternatives considered.

Capital costs for Alternative 7 are estimated to be approximately $\$ 5$ million. The 30 -year present-worth cost is estimated to range between $\$ 11$ million and $\$ 16$ million. Annual costs would be less than $\$ 1$ million. Taking into account recent field investigations within the TCE-contaminated portion of the shallow bedrock aquifer, capital costs for Alternative 4 are estimated to range from $\$ 6$ million to $\$ 12$ million; annual costs would range from $\$ 1$ million to $\$ 2$ million. For Alternative 8 , capital costs are estimated to be between $\$ 1$ million and $\$ 3$ million; annual costs would be approximately $\$ 0.5$ million.

Capital costs for Alternative 9 are estimated to be on the order of $\$ 0.5$ million and incorporate costs for the installation of injection or application wells and the application of chemical reagents. This is the most cost-effective alternative with regard to TCE treatment, although treatment of TCE is not necessary to ensure protectiveness. 


\section{PROPOSED ACTION}

The proposed action provides for active remediation of the TCE-contaminated groundwater in Zones 1 and 2 via in-situ chemical oxidation as described in Alternative 9, combined with longterm monitoring of groundwater and springs at the chemical plant area as described in Alternative 3.

The treatment method involves the introduction of Fenton-like reagents (e.g., hydrogen peroxide and a ferrous compound) into the groundwater as a means of treating TCE in place. Once introduced into the aquifer, the chemicals would produce hydroxyl radicals under controlled acidic conditions. These highly reactive radicals would then be expected to react with the TCE in the groundwater to form innocuous end products (i.e., chloride salts, $\mathrm{CO}_{2}$, and water). This chemical reaction can be completed in a relatively short period of time (days), once injection is achieved. The period of time required for remediation by using this technology is estimated to be on the order of a few months.

Long-term monitoring of an optimized network of wells and springs would generate the necessary data to verify assumptions and ensure continued protection. The long-term monitoring and assessment strategy will be designed to confirm that the contaminated zones are not progressing and that contaminant levels are diminishing with time. The decrease in contaminant concentrations is expected as a result of the source removals performed under the chemical plant ROD (DOE 1993) and the continued occurrence of natural processes, primarily dilution and dispersion.

The proposed action was developed after careful consideration of a full range of treatment technologies and remedial options. Because of geochemical and hydrogeological constraints, it is not technically practicable to achieve ARARs (MCLs) throughout the contaminated zones in a reasonable time frame using any of the remedial alternatives that were evaluated. However, it is considered feasible to effect some localized cleanup in certain contaminated zones where the aquifer yields are uncharacteristically high. When evaluated against the remedy selection criteria defined in the NCP (EPA 1990), Alternative 9 (in-situ chemical oxidation of the TCE in Zones 1 and 2) is the best option for localized remediation because it offers the greatest potential for short-term reduction of the predominant potential risk driver, TCE, and can be implemented quickly and inexpensively relative to pump and treat options. Successful in-situ treatment of the TCE would eliminate or decrease TCE concentrations and would result in risk estimates falling within the acceptable risk range for the hypothetical residential scenario.

Localized pump and treat options for other contaminants are not proposed because technical practicability is highly uncertain, and even optimal performance would not substantially decrease remediation time frames over that of natural attenuation processes. The uncertainty is associated primarily with the complex hydrogeology and heterogeneous geology of the site. Investigations indicate that the sustainable yield from the Burlington-Keokuk limestone ranges from 
$1.2 \mathrm{~L} / \mathrm{min}(0.3 \mathrm{gpm})$ up to less than $37.9 \mathrm{~L} / \mathrm{min}(10 \mathrm{gpm})$. Previous investigations indicated that the average sustainable yield from wells constructed in both the weathered and unweathered portions of the Burlington-Keokuk limestone is $1.2 \mathrm{~L} / \mathrm{min}(0.3 \mathrm{gpm})$. This particular characteristic of the aquifer results in implementability limitations where contaminants occur in both units.

A long-term pump test was performed in the area of TCE-contaminated groundwater to assess the effects of groundwater withdrawal in a more conductive portion of the weathered Burlington-Keokuk limestone. This test indicated that although the aquifer south of Raffinate Pits 3 and 4 was more transmissive than previously estimated, recharge is limited by structural controls, which results in dewatering of the area. Groundwater was withdrawn during the test at a rate of approximately $37.9 \mathrm{~L} / \mathrm{min}(10 \mathrm{gpm})$; however, on the basis of drawdown in the pumping well, this rate could not be sustained for an extended period. This information, in addition to other hydrogeologic parameters estimated from this field study, was useful in determining that the application of a pump and treat technology is not technically practicable.

Natural attenuation is proposed as a component of the remedy because the available information indicates that the zones of contamination are stable (i.e., they are not expanding), that contaminant levels will diminish with time at a rate comparable to that achieved through any active measures, and that this can be demonstrated or confirmed through empirical and statistical methods. While natural attenuation is considered an important component of the proposed remedy, it is recognized that certain expectations generally associated with MNA remedies will not be achieved in this circumstance. As with the active remedial methods that were evaluated, this approach is not expected to result in the achievement of ARARs (MCLs) throughout the contaminated zones over a time frame that can be planned for. Also, sophisticated groundwater modeling is not proposed because complex hydrogeological conditions and the mechanisms of attenuation limit the usefulness of this approach.

Details of the optimum monitoring network of wells, the monitoring scheme, and the in-situ chemical oxidation process will be presented in remedial design planning documents developed subsequent to the ROD. As required by CERCLA, a review would be conducted every five years because contaminants would remain in site groundwater at levels above those that allow for unlimited use and unrestricted exposure.

The proposed action is considered protective because there is no direct exposure to groundwater under current and foreseeable land uses, that is, land use is expected to remain recreational. However, the groundwater has been defined by the EPA as potentially useable (EPA 1986; MK-Ferguson 1990); therefore, deed restrictions or other institutional controls will be recorded as part of the proposed action to ensure against the potential use of the groundwater for drinking water purposes. 
The following MCLs or more stringent state standards are considered chemical-specific ARARs for the contaminated groundwater:

\section{Chemical Remediation Goal}

$\begin{array}{lr}\text { Nitrate } & 10 \mathrm{mg} / \mathrm{L} \\ \text { TCE } & 5 \mu \mathrm{g} / \mathrm{L} \\ \text { Nitrobenzene } & 17 \mu \mathrm{g} / \mathrm{L} \\ 2,4-D N T & 0.11 \mu \mathrm{g} / \mathrm{L} \\ 1,3-\mathrm{DNB} & 1 \mu \mathrm{g} / \mathrm{L}\end{array}$

Current groundwater levels for nitrobenzene and 1,3-DNB meet their respective ARARs. The proposed MCL of $20 \mathrm{ug} / \mathrm{L}$ for uranium is regarded as a to-be-considered requirement (TBC) for this action.

With respect to nitrate and 2,4-DNT, the state of the current technology and the complex hydrogeologic characteristics of the site render compliance with the requirements technically impracticable. Accordingly, the ROD will contain a waiver of the ARARs for nitrate and 2,4-DNT for all the contaminated zones on the basis of technical impracticability per $\$ 121$ (d)(4) of CERCLA and $\$ 300.430$ of the NCP (EPA 1990). With respect to TCE, it is intended that the proposed action will achieve the ARAR for TCE in Zones 1 and 2 (TCE has not been detected at the remaining zones). However, considerable uncertainty is associated with achieving this goal because of the innovative nature of the technology and the complex hydrogeologic characteristics of Zones 1 and 2. Since the Supplemental FS (DOE 1999) established that the pump and treat option is not effective for Zones 1 and 2, if the ARAR for TCE is not achieved after completion of the treatment component in accordance with the RD/RA work plan, a waiver of the ARAR for TCE in Zones 1 and 2 will be appropriate.

A number of factors associated with the shallow groundwater system beneath the chemical plant area are strong indicators that it would be technically impracticable to achieve reduction of the contaminant levels to meet ARARs within a reasonable time frame. These factors are as follows:

- The hydrogeology present in the shallow groundwater system is highly complex and unfavorable (i.e., karst features such as paleochannels, conduits, fractures, weathering, and dissolution features) for remediation using extraction methods;

- The hydraulic conductivity of the shallow groundwater system is highly heterogeneous and anisotropic; 
- Sustainable yield (i.e., the maximum rate of groundwater removal that can be sustained by pumping without dewatering the groundwater system) is low $(<37.9 \mathrm{~L} / \mathrm{min}[<10 \mathrm{gpm}])$;

- The area of influence of the extraction well is structurally controlled;

- The distribution of contaminants is complex (i.e., multiple historical sources introduced into a complex shallow groundwater system) and, in general, of low concentration;

- In spite of source removal at the ground surface, residual contaminants are likely to be present in undefinable and irremovable quantities in the karst features beneath the chemical plant area;

- Cleanup times estimated by using very optimistic extraction rates are still excessively long (i.e., hundreds to thousands of years, depending on the contaminant of concern); and

- Pumping tests performed at the site demonstrated that cleanup times would be excessive because of low yields, long recovery times for groundwater levels, and a high potential for dewatering the adjacent porous medium. 


\title{
8 COMMUNITY PARTICIPATION
}

Input from the public is an important element of the decision-making process for cleanup actions at the chemical plant area. Comments on all the alternatives evaluated and the proposed remedial action will be received during the public review period from August 3 through September 1, 1999. Oral comments will be received at a public meeting to be held (during the week of August 23, 1999) for this action. Written comments may either be submitted at the public meeting or mailed before the close of the comment period to:

\author{
Stephen H. McCracken \\ Project Manager for WSSRAP \\ U.S. Department of Energy \\ Weldon Spring Site Remedial Action Project Office \\ 7295 Highway 94 South
}

St. Charles, Missouri 63304

Information relevant to the proposed remedial action is located in the administrative record and public document rooms at the WSSRAP site office. Additional information repositories have been established at the following five locations:

\author{
Kathryn M. Linneman Branch \\ Francis Howell High School \\ St. Charles City/County Library \\ 7001 Highway 94 South \\ 2323 Elm Street \\ St. Charles, Missouri 63304 \\ St. Charles, Missouri 63301 \\ Spencer Creek Branch \\ Middendorf-Kredell Library \\ St. Charles City/County Library \\ 427 Spencer Road \\ St. Charles City/County Library \\ 2750 Highway K \\ St. Peters, Missouri 63376 \\ O'Fallon, Missouri 63366 \\ Kisker Road Branch \\ St. Charles City/County Library \\ 1000 Kisker Road \\ St. Peters, Missouri 63304
}

Information on file at these repositories includes the RI (DOE and DA 1997b), BRA (DOE and DA 1997a), FS (DOE and DA 1998), Supplemental FS (DOE 1999), the chemical plant ROD (DOE 1993), and this Proposed Plan for remedial action. Supporting technical reports are available in the public reading room at the WSSRAP site office. For additional information, the DOE can be contacted at the address provided above. The telephone number for the WSSRAP site office is 
(314) 441-8086. The remedial project manager for the EPA who can supply additional information is:

Mr. Daniel Wall

U.S. Environmental Protection Agency

Region VII

901 N. Fifth Street

Kansas City, Kansas 66101

(913) 551-7710 


\section{REFERENCES}

American Cancer Society, 1992, Cancer Facts \& Figures-1992, Atlanta, GA.

DOE and DA: see U.S. Department of Energy and U.S. Department of the Army.

EPA: see U.S. Environmental Protection Agency.

MK-Ferguson Company and Jacobs Engineering Group, 1990, Groundwater Classification for the Weldon Spring Site Remedial Action Project, Weldon Spring, Missouri, DOE/OR/21548-116, prepared for U.S. Department of Energy, Oak Ridge Field Office, Weldon Spring Site Remedial Action Project, Weldon Spring, MO, April.

MK-Ferguson and Jacobs Engineering Group, 1999, Weldon Spring Site Remedial Action Project: Weldon Spring Site Environmental Report for Calendar Year 1998, Revision A, DOE/OR/21548773, prepared for U.S. Department of Energy, Oak Ridge Field Office, Weldon Spring Site Remedial Action Project, Weldon Spring, MO, July.

National Safety Council, 1995, Accident Facts, Itasca, IL.

U.S. Department of Energy, 1990, Record of Decision for the Management of the Bulk Wastes at the Weldon Spring Quarry, Rev. 0, DOE/OR/21548-317, St. Charles, MO, Sept.

U.S. Department of Energy, 1992, Remedial Investigation for the Chemical Plant Area of the Weldon Spring Site, DOE/EIS-0185D (DOE/OR/21548-074, Vol. I), prepared by MK-Ferguson Company and Jacobs Engineering Group, Inc., Weldon Spring, MO., for U.S. Department of Energy, Oak Ridge Field Office, Weldon Spring Site Remedial Action Project, Weldon Spring, MO, Nov.

U.S. Department of Energy, 1993, Record of Decision for Remedial Action at the Chemical Plant Area of the Weldon Spring Site, DOE/OR/21548-376, prepared by U.S. Department of Energy, Oak Ridge Field Office, Weldon Spring Site Remedial Action Project, Weldon Spring, MO, Sept.

U.S. Department of Energy, 1998a, Record of Decision for Remedial Action for the Quarry Residuals Operable Unit at the Weldon Spring Site, Weldon Spring, Missouri, DOE/OR/21548-725, prepared by U.S. Department of Energy, Oak Ridge Operations Office, Oak Ridge, TN, Sept.

U.S. Department of Energy, 1998b, Weldon Spring Site Environmental Report for Calendar Year 1997, Revision 0, DOE/OR/21548-730, prepared by MK-Ferguson Company and Jacobs Engineering Group, St. Charles, MO, for U.S. Department of Energy, Oak Ridge Operations Office, Oak Ridge, TN, Aug. 
U.S. Department of Energy, 1999, Supplemental Feasibility Study for Remedial Action for the Groundwater Operable Unit at the Chemical Plant Area of the Weldon Spring Site, Weldon Spring, Missouri, DOE/OR/21548-783, prepared by Argonne National Laboratory, Argonne, IL, for U.S. Department of Energy, Weldon Spring Site Remedial Action Project, Weldon Spring, MO, June.

U.S. Department of Energy and U.S. Department of the Army, 1997a, Baseline Risk Assessment for the Groundwater Operable Units at the Chemical Plant Area and the Ordnance Works Area, Weldon Spring, Missouri, DOE/OR/21548-568, prepared by Argonne National Laboratory, Argonne, IL, for U.S. Department of Energy, Weldon Spring Site Remedial Action Project, Weldon Spring, MO, and U.S. Department of the Army, Corps of Engineers, Kansas City District, Kansas City, MO, July.

U.S. Department of Energy and U.S. Department of the Army, 1997b, Remedial Investigation for the Groundwater Operable Units at the Chemical Plant Area and the Ordnance Works Area, Weldon Spring Site, Weldon Spring, Missouri, DOE/OR/21548-571, prepared by MK-Ferguson Company and Jacobs Engineering Group, Inc., Weldon Spring, MO, and Argonne National Laboratory, Argonne, IL, for U.S. Department of Energy, Weldon Spring Site Remedial Action Project, Weldon Spring, MO, and U.S. Department of the Army, Corps of Engineers, Kansas City District, Kansas City, MO, July.

U.S. Department of Energy and U.S. Department of the Army, 1998, Feasibility Study for Remedial Action for the Groundwater Operable Units at the Chemical Plant Area and the Ordnance Works Area, Weldon Spring, Missouri, DOE/OR/21548-569, prepared by Argonne National Laboratory, Argonne, IL, for U.S. Department of Energy, Weldon Spring Site Remedial Action Project, Weldon Spring, MO, and U.S. Department of the Army, Corps of Engineers, Kansas City District, Kansas City, MO, Dec.

U.S. Environmental Protection Agency, 1986, Guidelines for Ground-Water Classification under the EPA Ground-Water Protection Strategy, Final Draft, Washington, DC.

U.S. Environmental Protection Agency, 1989, Risk Assessment Guidance for Superfund, Volume I: Human Health Evaluation Manual (Part A, Interim Final), EPA/540/1-89/001, Office of Emergency and Remedial Response, Washington, DC, Dec.

U.S. Environmental Protection Agency, 1990, "National Oil and Hazardous Substances Pollution Contingency Plan; Final Rule (40 CFR Part 300)," Federal Register 55(46):8666-8865, March 8.

U.S. Environmental Protection Agency, 1999, Use of Monitored Natural Attenuation at Superfund, RCRA Corrective Action, and Underground Storage Tank Sites, OSWER Directive 9200.4-17P, developed by the U.S. Environmental Protection Agency, Office of Solid Waste and Emergency Response, April [URL http://www.epa.gov/swerust1/directiv/9200_417.htm]. 